\title{
AN ANALYSIS OF THE RESPONSE OF THE RAFT RIVER MONITOR WELLS TO. THE 1979 INJECTION TESTS
}

\author{
Susan G. Spencer \\ Don M. Callan
}

6

Published September 1980

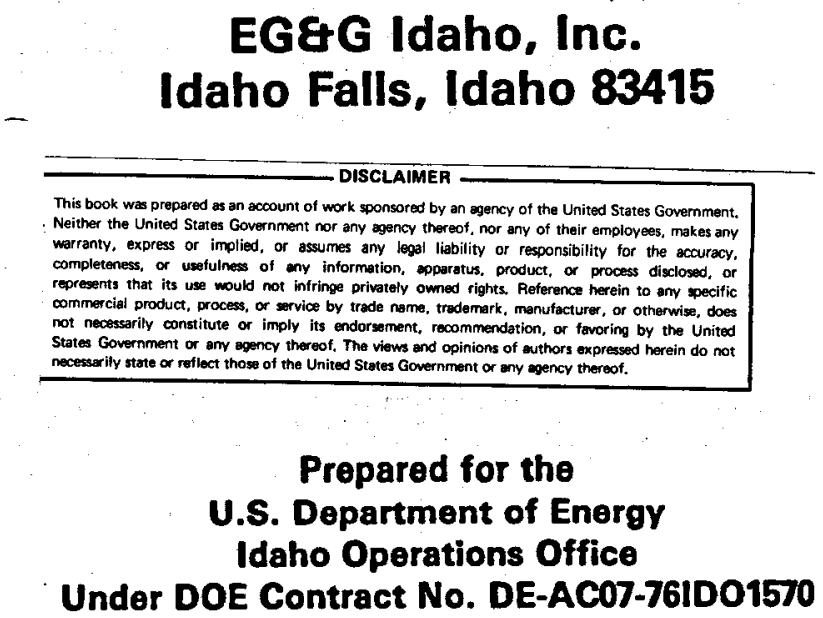




\section{DISCLAIMER}

This report was prepared as an account of work sponsored by an agency of the United States Government. Neither the United States Government nor any agency Thereof, nor any of their employees, makes any warranty, express or implied, or assumes any legal liability or responsibility for the accuracy, completeness, or usefulness of any information, apparatus, product, or process disclosed, or represents that its use would not infringe privately owned rights. Reference herein to any specific commercial product, process, or service by trade name, trademark, manufacturer, or otherwise does not necessarily constitute or imply its endorsement, recommendation, or favoring by the United States Government or any agency thereof. The views and opinions of authors expressed herein do not necessarily state or reflect those of the United States Government or any agency thereof. 


\section{DISCLAIMER}

Portions of this document may be illegible in electronic image products. Images are produced from the best available original document. 
ABSTRACT

\begin{abstract}
The geothermal resource for the Department of Energy's (DOE) Raft River Geothermal 5 MWe Power Project is located in a closed ground water basin in southcentral Idaho. Chemical analyses indicate the existence of natural communication along fractures between the geothermal reservoir and the shallower aquifers developed for irrigation. Much of the ground water that is presently used for irrigation is of poor quality. Injection of geothermal fluids at intermediate depths may increase communication between the reservoir and the aquifer, resulting in further degradation of shallow ground water quality over time. Seven monitor wells, ranging in depth from $150 \mathrm{~m}$ to $400 \mathrm{~m}$, were drilled to evaluate the potential for this degradation. Monitoring of these wells during
\end{abstract}

two 21-day injection tests at the Raft River Geothermal Injection Well-6 (RRGI-6) indicates two types of response in the shallow aquifer system:

1. The water level in Monitor Well-4 (MW-4) increased an average of $0.4 \mathrm{~m} /$ week during injection, indicating direct fracture connection between the injection zone and the aquifer penetrated by $M W-4$

2. Water levels in MW-5, MW-6 and MW-7 showed a "step function" decrease which coincided with the period of the injection tests. Analyses indicate that this response may be caused by elastic deformation in the aquifer matrix. 


\section{ACKNOWLEDGMENTS}

For their technical support and advice during the preparation of this report, the authors wish to thank B. D. Lewis and J. T. Barraclough of the U.S. Geological Survey; F. B. Sherman and
C. Leach of the Idaho Department of Water Resources; and M. R. Dolenc, K. S. Kennedy, K. P. McCarthy, D. Goldman, S. Petty, and L. Hull of EG\&G Idaho, Inc. 


\section{CONTENTS}

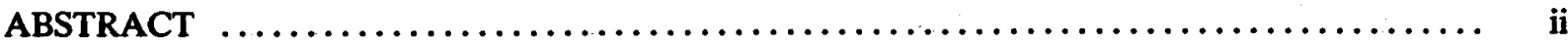

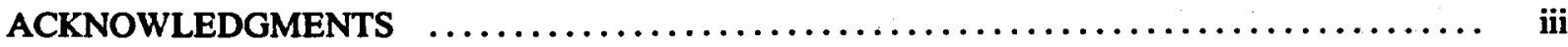

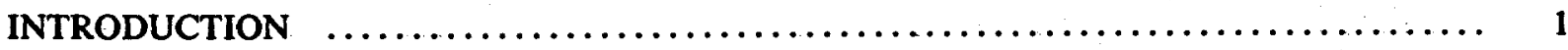

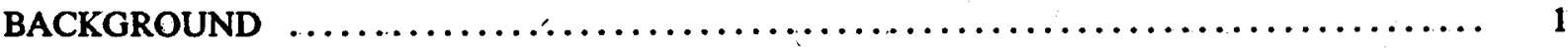

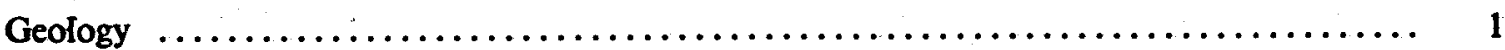

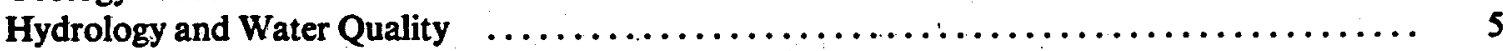

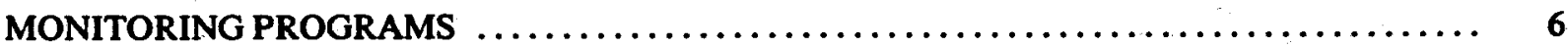

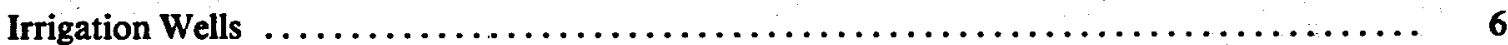

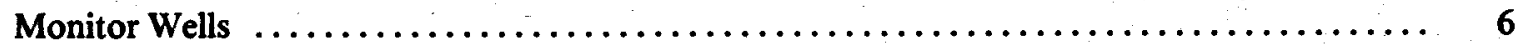

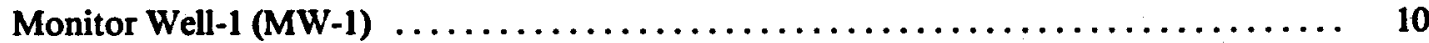

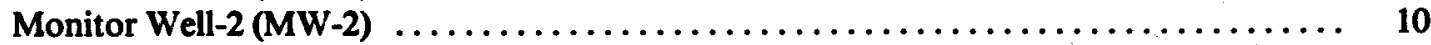

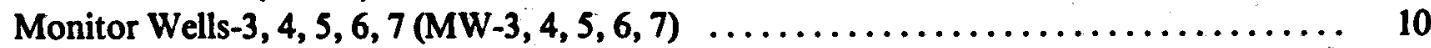

Raft River Geothermal Injection Well-4 (RRGI-4) Injection Tests .............. 10

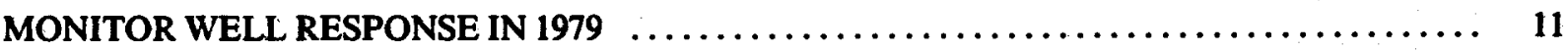

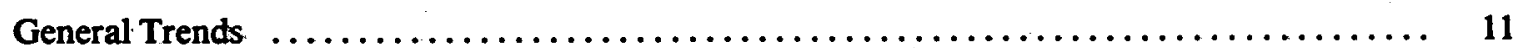

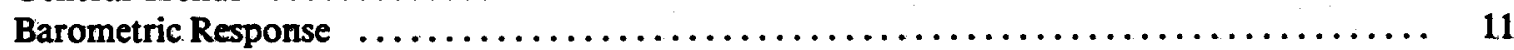

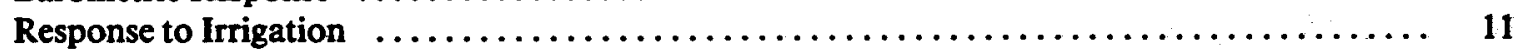

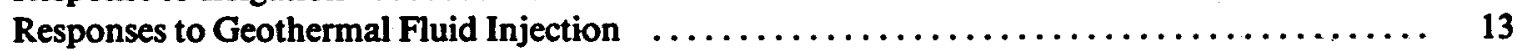

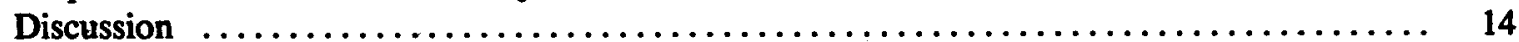

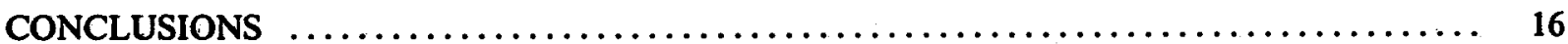

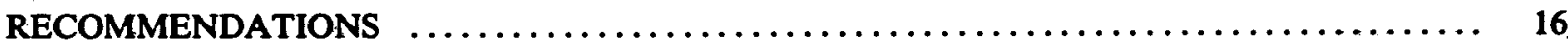

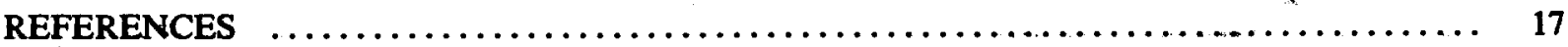

APPENDIX A-Monitor Well Logs $\ldots \ldots \ldots \ldots \ldots \ldots \ldots \ldots \ldots \ldots \ldots \ldots \ldots \ldots \ldots \ldots \ldots$

\section{FIGURES}

1. Raft River Geothermal Area and well locations $\ldots \ldots \ldots \ldots \ldots \ldots \ldots \ldots \ldots \ldots \ldots \ldots \ldots$

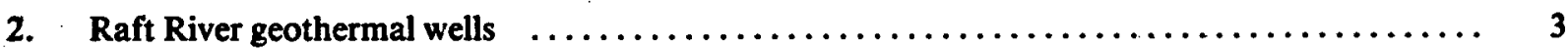

3. Physiography of the Raft River Valley $\ldots \ldots \ldots \ldots \ldots \ldots \ldots \ldots \ldots \ldots \ldots \ldots \ldots \ldots \ldots$

4a. Trilinear plot of chemical analyses from surface and ground water $\ldots \ldots \ldots \ldots \ldots \ldots \ldots$

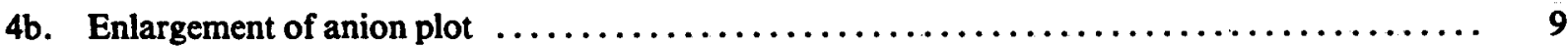

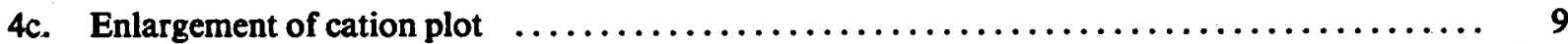




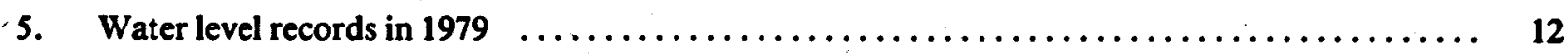

6. MW-4 water level record showing response to injection $\ldots \ldots \ldots \ldots \ldots \ldots \ldots \ldots \ldots$

7. MW-5, 6, 7 water level records illustrating aquifer distortion $\ldots \ldots \ldots \ldots \ldots \ldots \ldots \ldots \ldots$

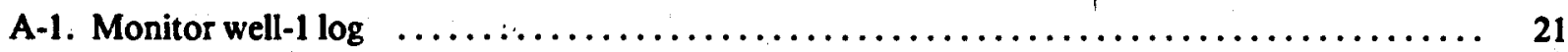

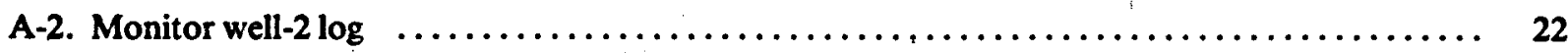

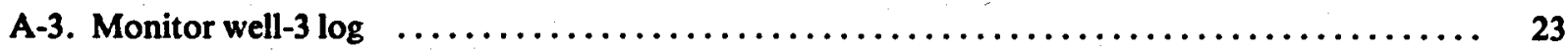

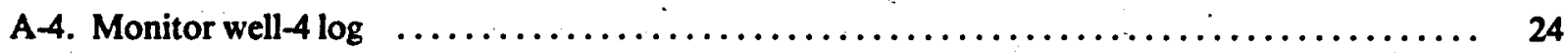

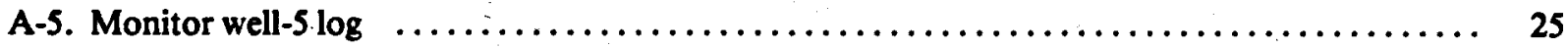

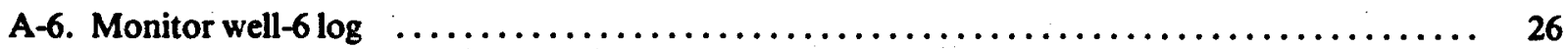

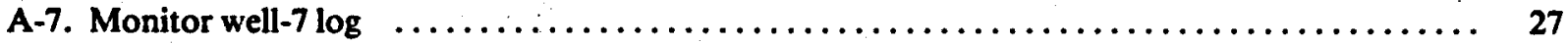

\section{TABLES}

1. Representative Analyses of Water from Selected Wells in the Raft

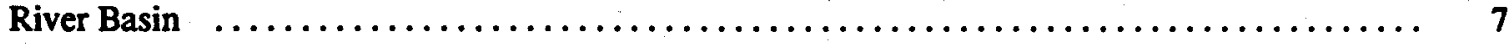

2. Key to Trilinear Plots in Figure $4 a \ldots \ldots \ldots \ldots \ldots \ldots \ldots \ldots \ldots \ldots \ldots \ldots \ldots \ldots \ldots$

3. Barometric Efficiencies of Monitor Wells 3 through $7 \ldots \ldots \ldots \ldots \ldots \ldots \ldots \ldots \ldots \ldots$ 


\section{AN ANALYSIS OF THE RESPONSE OF THE RAFT RIVER MONITOR WELLS TO THE 1979 INJECTION TESTS}

\section{INTRODUCTION}

Preliminary geological and geophysical work conducted by the U.S. Geological Survey (USGS) in 1973 and 1974 indicated a geothermal energy resource in the southern Raft River Valley, Idaho (Figure 1). Geochemical research based on shallow aquifer data suggested the presence of a $150^{\circ} \mathrm{C}$ resource at a depth of approximately $1300 \mathrm{~m}$. In late 1974, the U.S. Department of Energy (DOE), the Raft River Rural Electric Cooperative (RRREC), and the Idaho Department of Water Resources (IDWR) initiated a cooperative venture to investigate the generation of electrical energy using the moderate temperature geothermal fluid. The first deep exploratory well, Raft River Geothermal Exploratory Well-1 (RRGE-1), confirmed the presence of the resource. The Department of Energy (DOE) began design of a $5 \mathrm{MWe}$ binary power plant to demonstrate the technical feasibility and environmental acceptability of generating electricity.utilizing a binary cycle. Construction of the power plant began in August, 1978, with the plant scheduled to be operational by October 1980.

Seven geothermal wells were drilled to evaluate the production and injection possibilities of the reservoir. Production wells RRGE-1, RRGE-2, RRGE-3, and Raft River Geothermal Production Well-5 (RRGP-5) were drilled to depths of 1490 to $1980 \mathrm{~m}$ (Figure 2). Injection Wells RRGI-6 and RRGI-7 were drilled to a depth of $1160 \mathrm{~m}$ for injection. Well RRGI-4 was initially drilled as an injection well to a depth of $850 \mathrm{~m}$ and was later deepened to $1650 \mathrm{~m}$ and completed as a production well (RRGP-4).

RRGE-1, RRGE-2 and RRGE-3 will be pumped to produce the $150 \mathrm{~L} / \mathrm{s}$ at $140^{\circ} \mathrm{C}$ required to operate the power plant. Injection pumps have been installed at RRGI-6 and RRGI-7 to inject an estimated $120 \mathrm{~L} / \mathrm{s}$ at wellhead pressures of 2400 to $2800 \mathrm{kPa}$. The remainder of the fluid produced will be consumed in the plant cooling cycle. RRGP 4 and RRGP-5 were used for hydraulic fracturing experiments and are not considered an integral part of the present supply and injection system.

As DOE's geothermal development program continued, concerns were expressed about the effect that development might have on the quality and supply of ground water in the basin. Modeling of the shallow aquifers by the U.S. Geological Survey ${ }^{1}$ indicated that it would take 100 years for geothermal production to affect the shallow aquifers currently being developed for irrigation. There was concern, however, that high pressure injection at intermediate depths $(500-1000 \mathrm{~m})$ would adversely affect nearby irrigation wells.

Because of this concern, DOE has established a monitoring program to evaluate the potential for these adverse effects. Eight wells drilled by DOE and the USGS were monitored during injection tests in 1979. This report summarizes the data collected on the water level changes in these wells during these injection tests and presents an analysis of these responses.

\section{BACKGROUND}

\section{Geology}

The Raft River Valley is a structural downthrown block bounded by the Jim Sage and Cotterel Mountains the west, the Raft River Range on the south, and the Black Pine and Sublett Ranges on the east (Figure 3). The Jim Sage and Cotterel Mountains are primarily Tertiary volcanic and sedimentary rocks. The Black Pine and Sublett Ranges are composed of Paleozoic limestones and sandstones. The Raft River Range, an anomalous east-west trending range, contains Precambrian adamellite and Paleozoic sediments. 2

The deepest wells in the valley terminate in quartz monzonite, indicating that the floor of the basin is similar to the Precambrian rocks exposed in the Raft River Range. Precambrian quartzites and schists overlie the basement rock and are 


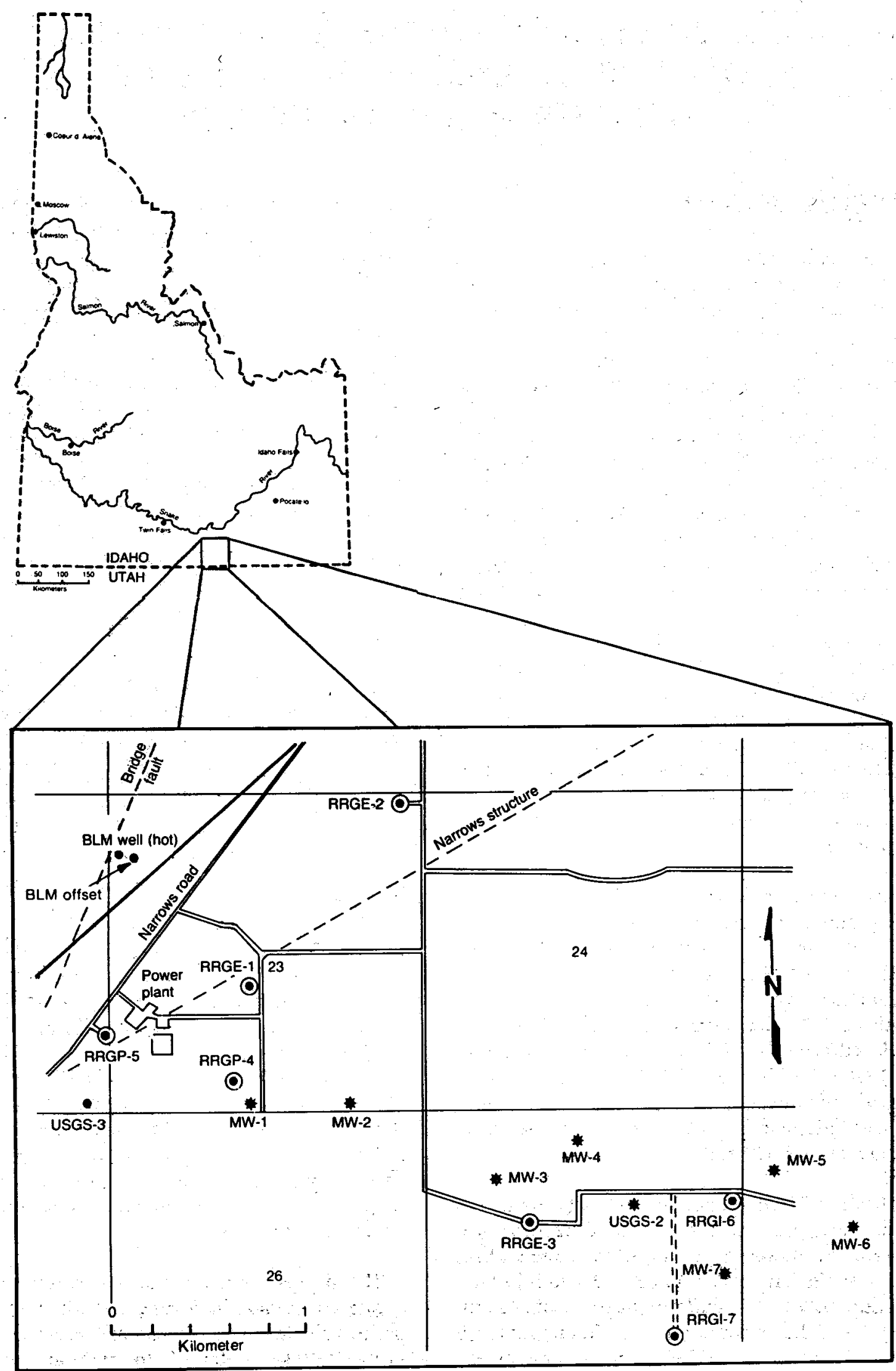

Figure 1. Raft River Geothermal Area and well locations. 


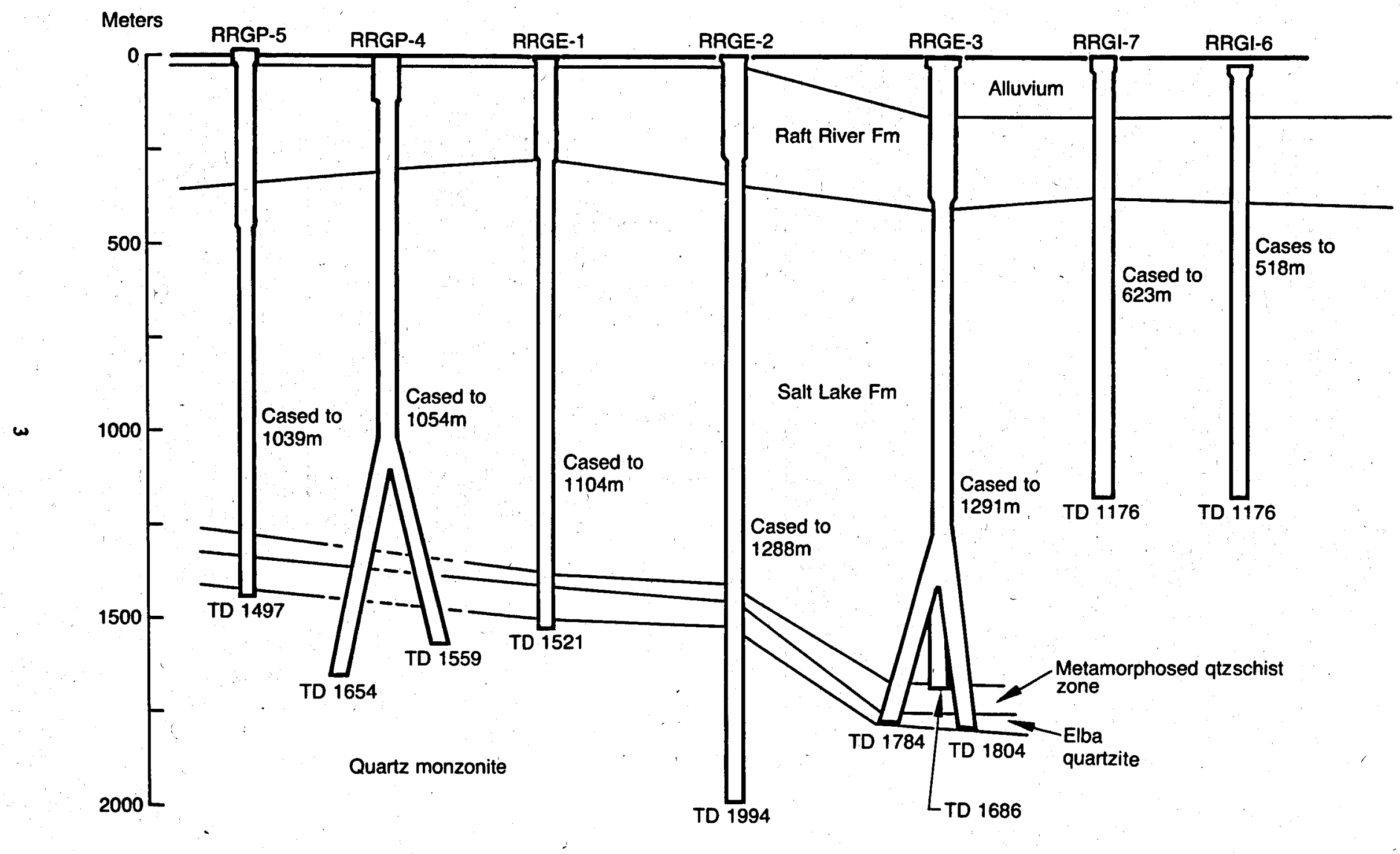

Figure 2. Raft River geothermal wells. 

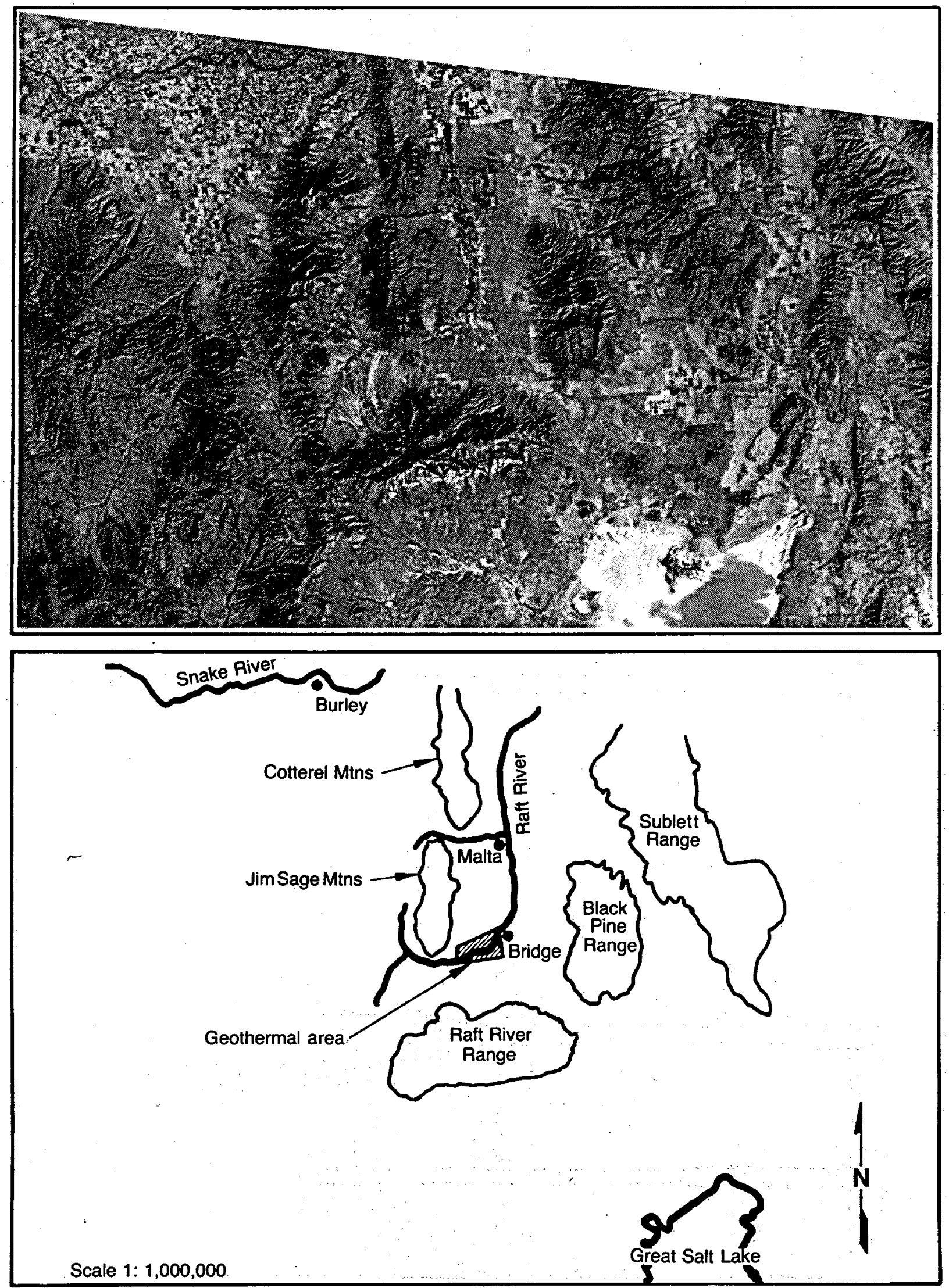

Figure 3. Physiography of the Raft River Valley. 
themselves overlain with sediments of the Tertiary Salt Lake Formation. This formation, which constitutes the majority of the basin sediments, consists of unconsolidated quartzose silts and sands, tuff, quartzite and rhyolite gravels. The Salt Lake Formation is overlain by Pleistocene sand, gravel, silt and clay of the Raft Formation. .The youngest deposits in the basin are alluvial and fluvial sediments (see Reference 2).

The meandering Raft River has cut through the deposits near the center of the valley and has contributed to the depositional and erosional sequences. The variety of sediment sources and transport mechanisms complicates lithologic correlation of the upper $300 \mathrm{~m}$ of sediments in the southern Raft River Valley.

The basin is a downthrown block in contrast to the upthrown Jim Sage Mountains. The steep, north-south trending fault scarp on the east face of the Jim Sage Mountains has a displacement of $900 \mathrm{~m}$. This steep fault scarp has resulted in numerous landslides and alluvial fans which are intrinsic to the filling of the valley. 3

The structural geology plays a key role in the production of geothermal fluids in the resource area. The present interpretation of the production mechanism is that detached-normal faulting of the Tertiary Salt Lake Formation sediments provides a highly-fractured and permeable rock section that allows for fluid movement. Recharge is apparently provided by the numerous faults at or near the valley surface, while thermal convection within the metamorphosed basement section is thought to provide the heat source.

\section{Hydrology and Water Quality}

The Raft River basin encompasses an area of $3870 \mathrm{~km}^{2}$ in southcentral Idaho and northern Utah. Precipitation ranges from $25 \mathrm{~cm}$ per year in the valley to over $80 \mathrm{~cm}$ in the surrounding mountains. The principal stream in the basin is the Raft River, which originates in the Goose Creek Mountains in northwestern Utah and flows east and north to its confluence with the Snake River.

During the summer months, nearly all surface water in the basin is diverted for irrigation. Consequently, flow in the Raft River is totally dissipated between Bridge and Malta during the irrigation season. The Raft River is primarily a losing stream in the vicinity of the geothermal development, a condition which is enhanced by a declining water table during late spring and summer. ${ }^{4}$

Ground water in the basin occurs both in unconfined and confined conditions in the poorly consolidated sediments of the Salt Lake Formation, and in the sands and gravels of the Raft Formation and recent alluvial deposits. ${ }^{5}$ Recharge to these aquifers results from precipitation in the surrounding mountains and infiltration from streams and irrigation water. Walker and others (see Reference 5) estimate that the upper $60 \mathrm{~m}$ of saturated deposits contain $11 \mathrm{~km}^{3}$ of water. Based on an analysis of precipitation and evapotranspiration, the groundwater yield of the basin was estimated at less than $0.2 \mathrm{~km}^{3}$ (see Reference 5).

The shallow aquifers can be considered water table aquifers, although some wells reveal locally confined conditions. Piezometric surfaces in several of the geothermal production wells are over $100 \mathrm{~m}$ above land surface. Because of this increase in head with depth, each aquifer is probably recharged, in part, by upward leakage from underlying aquifers (see Reference 1). In the geothermal area, wells as shallow as $120 \mathrm{~m}$ tap hot water, and nearly all irrigation wells in the area show chemical and thermal evidence of upward leakage from the geothermal resource.

Ground water withdrawal for irrigation in the basin has increased substantially since 1948 . Most irrigation wells are concentrated in an area within $3 \mathbf{~ k m}$ of the Raft River, and ground water level declines along the river have been most severe. Measurements of water levels since 1952 show more than $15 \mathrm{~m}$ of decline north of Malta and nearly $6 \mathrm{~m}$ of decline just east of the geothermal development (see Reference 1). In 1963, the state of Idaho declared the basin a critical ground water area, closing it to further ground water development. The subsequent study of the basin by Walker and others (see Reference 5) indicated that a total of more than $0.6 \mathrm{~km}^{3}$ of ground water had been removed from storage by the end of the 1966 irrigation season.

Ground water quality varies widely in the basin. The total dissolved solids (TDS) concentration of well and spring water averages $750 \mathrm{mg} / \mathrm{L}$ and ranges from $120 \mathrm{mg} / \mathrm{L}$ to $3200 \mathrm{mg} / \mathrm{L}$ (see Reference 5). Most of the ground water is of the 
sodium chloride or calcium bicarbonate type. Variations are induced by well depth and location with respect to streams, areas of irrigation water recharge, and areas of recharge from deeper aquifers.

A summary of chemical analyses from ground water in selected wells is shown in Table I. Water from wells in the vicinity of the geothermal area has elevated temperatures and total dissolved solids, a result of mixing of shallow ground water with recharge from the geothermal reservoir. For example, water from a well $20 \mathrm{~km}$ west of the geothermal area (15S24E27daal) has a temperature of $13^{\circ} \mathrm{C}$ and TDS of $720 \mathrm{mg} / \mathrm{L}$, while water from a well within the geothermal area (15S26E23abd1) has a temperature of $29^{\circ} \mathrm{C}$ and TDS of $2400 \mathrm{mg} / \mathrm{L}$. These wells are approximately the same depth.

Analyses of water samples from the geothermal wells show a variation in TDS (Table I). The basis for this variation is not clear due to the limited number of data points. Trilinear plots (Figure 4a, $4 b$; and $4 c$ and Table 2) of water chemistry from shallow and deep wells indicate that the geothermal fluids are of similar percentage composition, even though the TDS may differ. The linearity of the anion and cation plots. (Figure 4a) suggests. dilution of the rising geothermal fluids resulting from recharge to the valley.

An enlargement of the anion plot (Figure 4b) indicates that there are several groups of wells in the high chloride region. Geothermal wells RRGE-1 and RRGP-5 plot in a different location than RRGE-3, RRGI-6 and RRGI-7, indicating that there are variations within the geothermal reservoir. Differences between the order of geothermal wells on the cation and anion plots may be due to reactions occurring in the water as it moves up the fractures. The juxtaposition of shallower wells such as MW 4 and geothermal wells such as RRGI-6 indicates that these wells may directly intersect fractures that conduct geothermal fluids upward. It would not be surprising to see these wells respond to the production or injection of geothermal fluids. The location of other shallow warm wells (such as 15S26E23abdl) on the plot indicates that the water from these wells is a mixture of geothermal fluids and shallow ground water.

\section{MONITORING PROGRAMS}

Since 1974, DOE and Idaho Department of Water Resources (IDWR) have conducted a series of geochemical and environmental monitoring programs. The objectives of these programs are to:

1. Determine the extent of natural communication between aquifers in Raft River

2. Monitor the chemical and hydrologic effects of the geothermal development

3. Predict the long-term impacts of geothermal development on the shallow aquifers developed for domestic use and irrigation.

\section{Irrigation Wells}

The initial monitoring programs included semiannual chemical analyses of water taken from 22 irrigation wells near the geothermal development. Several problems were encountered during the monitoring program which limit the usefulness of the data. These problems included the following:

1. Access to the irrigation wells was limited to the irrigation season (April to October)

2. Wells pumped one year were not necessarily pumped the next

3. Significant seasonal variations in the pumping rates of individual wells exist

4. Information about the depth and construction of irrigation wells is difficult to obtain or is nonexistent.

\section{Monitor Wells}

An interagency (DOE, USGS, IDWR) meeting was held in 1976 to review the irrigation well monitoring program and to make recommendations for a new program. The recommendations included the drilling of a series of monitor wells in the valley to solve some of the problems encountered in the irrigation well monitoring. The 
Table 1. Representative analyses of water from selected wells in the Raft River Basin

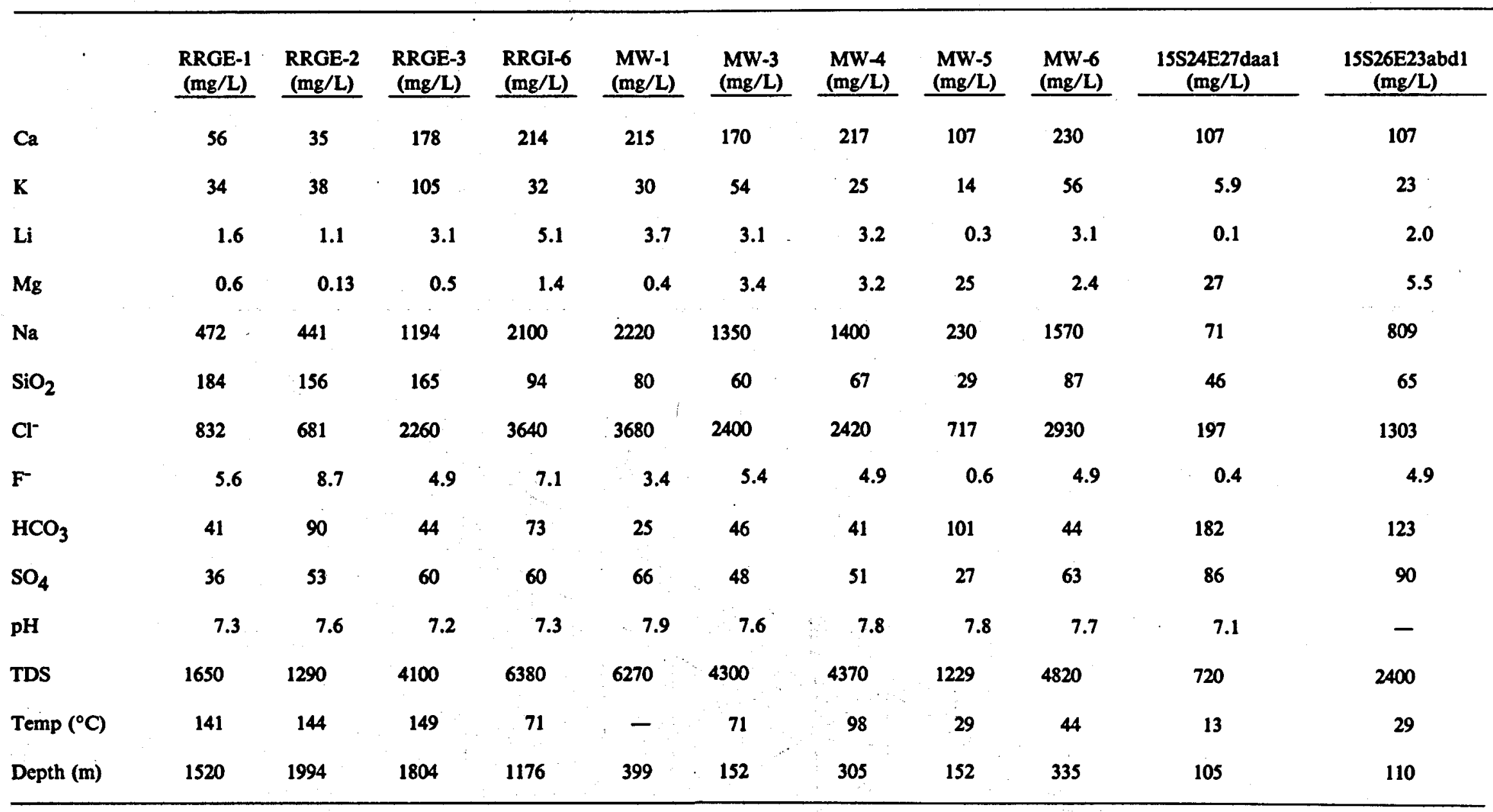




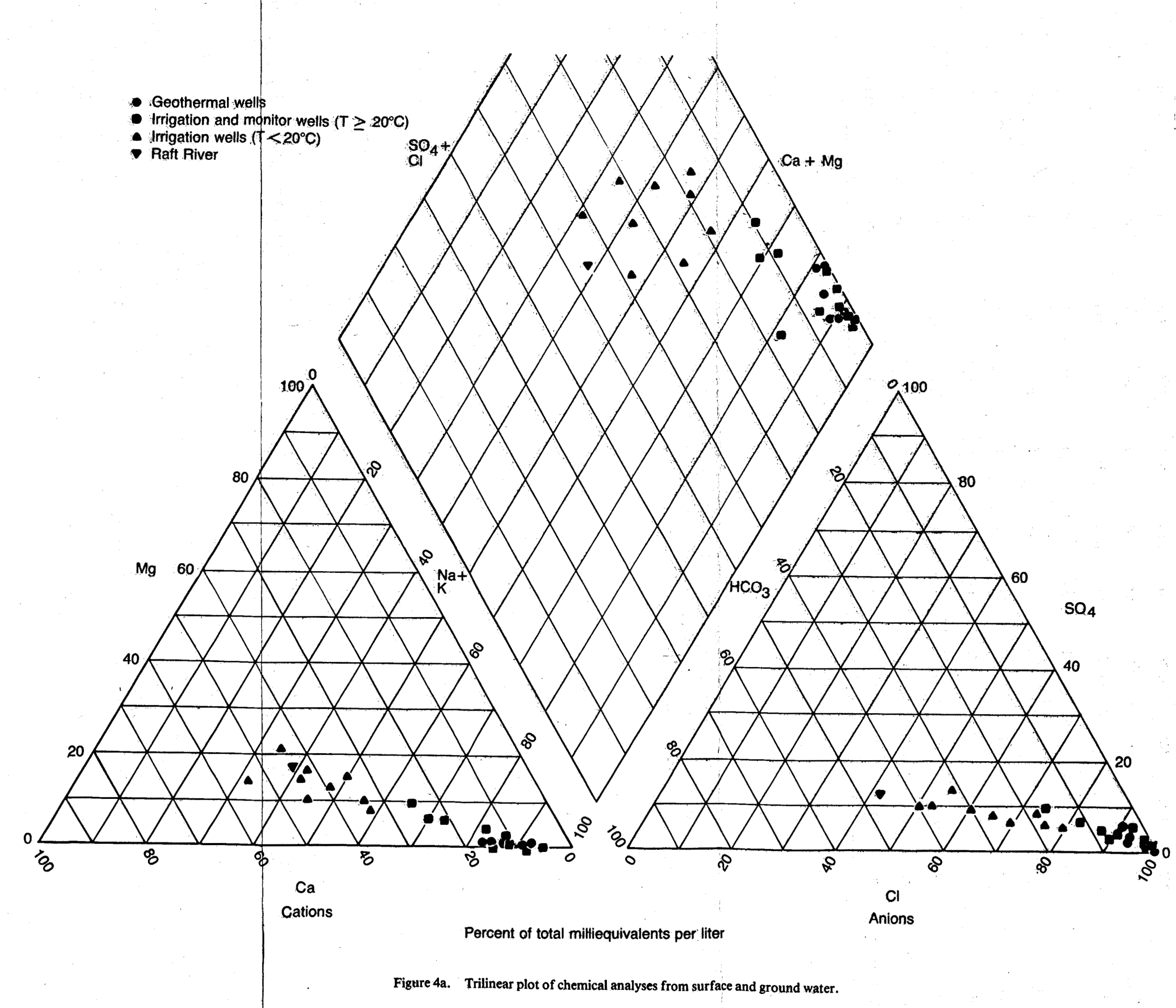




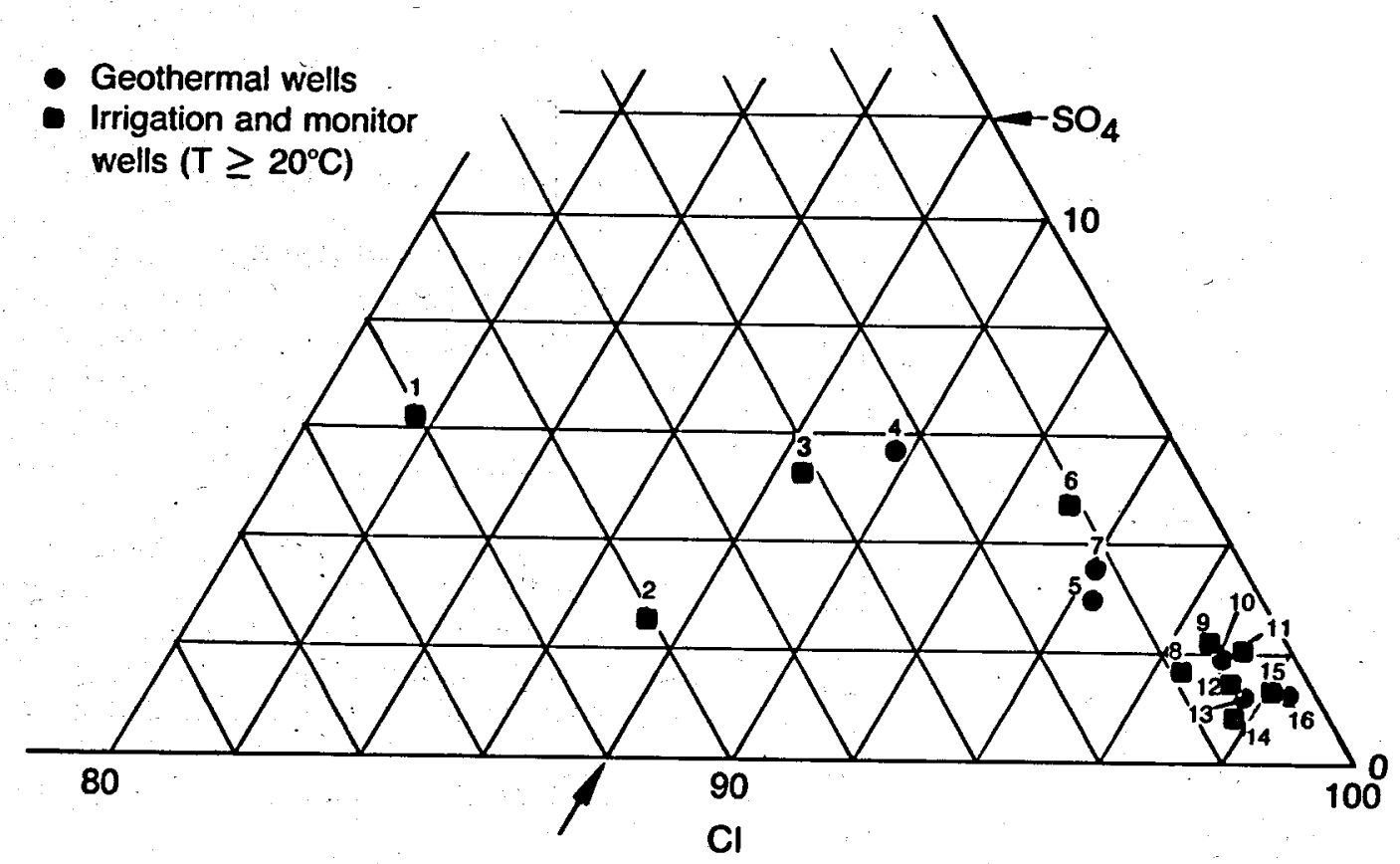

Percent of total milliequivalents per liter

Figure 4b. Enlargement of anion plot.

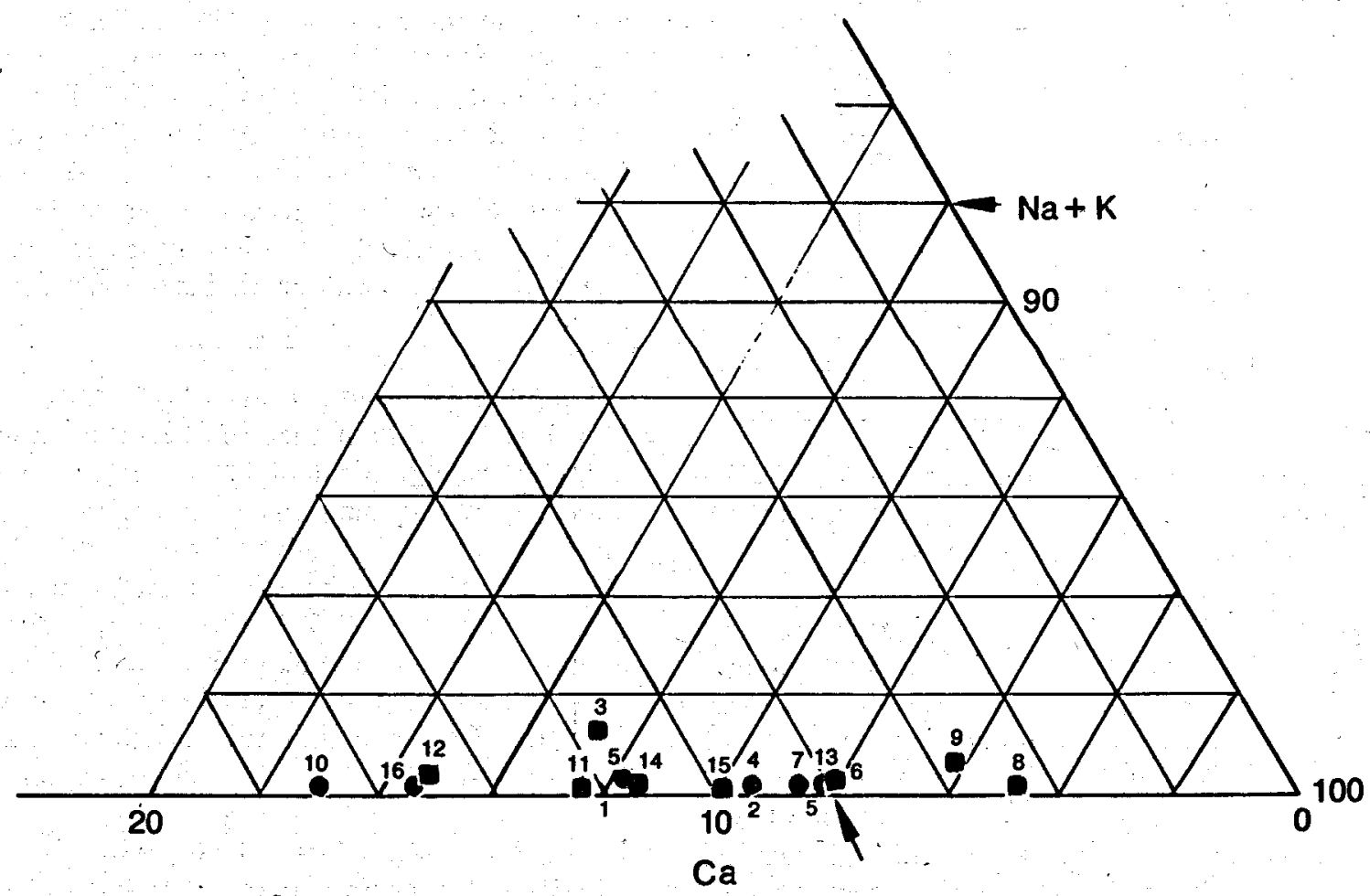

Percent of total milliequivalents per liter

Figure 4c. Enlargement of cation plot. 
Table 2. Key to trilinear plots in Figure 4a

\begin{tabular}{|c|c|c|}
\hline & Well & $\begin{array}{l}\text { Depth } \\
\text { (m) }\end{array}$ \\
\hline 1. & 15S27E19CCC1 & 125 \\
\hline 2. & MW-7 & 152 \\
\hline 3. & 15S26E23abd1 & 110 \\
\hline 4. & RRGE-2 & 1994 \\
\hline 5. & RRGE-1 & 1520 \\
\hline 6. & BLM & 126 \\
\hline 7. & RRGP-5 & 1501 \\
\hline 8. & USGS-3 & 434 \\
\hline 9. & MW-6 & 335 \\
\hline 10. & RRGE-3 & 1804 \\
\hline 11. & Crook's & 165 \\
\hline 12. & MW-4 & 305 \\
\hline 13. & RRGI-6 & 1176 \\
\hline 14. & USGS-1 & 336 \\
\hline 15. & MW-1 & 399 \\
\hline 16. & RRGI-7 & 1176 \\
\hline
\end{tabular}

monitor wells were to be located so that potential changes would be detected prior to actual effects in nearby irrigation and domestic wells.

When DOE funding became available for the monitor well program, only one injection well, RRGI-4, had been located. Monitor wells MW-1 and MW-2 were drilled to monitor injection tests in that well. Since that time, five more monitor wells have been drilled. These seven wells and three USGS exploratory holes (USGS-2, USGS-3, and the BLM Offset well) form the nucleus of the injection monitoring program at Raft River. Each of the wells is equipped with either a Stevens water level recorder or a digiquartz pressure transducer to provide continuous records of fluctuations in the piezometric surface in each well. Information on well completion, water chemistry, water temperature, and the lithology of the formations penetrated by each of the wells is presented in Appendix A and is summarized below.

Monitor Well-1 (MW-1). MW-1 is located $200 \mathrm{~m}$ to the southeast of RRGI-4 (see Figure 1) and was drilled to a depth of $400 \mathrm{~m}$. The well has a shut-in pressure of $300 \mathrm{kPa}$. The quality of the water produced from MW-1 is nearly the worst encountered in the basin (refer to Table 1).

Monitor Well-2 (MW-2). MW-2 was drilled near the Crook hot well to monitor the effects of injection on the Crook well and the effects on the shallow aquifer of pumping this well. Borehole temperatures in the well exceeded $90^{\circ} \mathrm{C}$ at $80 \mathrm{~m}$, but significant fluid production was not encountered until a depth of $160 \mathrm{~m}$ was reached.

Monitor Wells-3, 4, 5, 6, 7 (MW-3, 4, 5, 6, 7). MW-3, MW-4, MW-5, MW-6, and MW-7 were located and drilled to monitor injection in RRGI-6 and RRGI-7. MW-3, which is $152 \mathrm{~m}$ deep, and MW-4, which is $305 \mathrm{~m}$.deep, reveal similar conditions. The average temperature gradient in these two wells $\left(26^{\circ} \mathrm{C} / 100 \mathrm{~m}\right)$ is the highest gradient encountered in the five monitor wells drilled near RRGI-6 and RRGI-7. The elevation of the water level in MW-4 is $1470 \mathrm{~m}$ (datum National Geodetic Vertical Datum of 1929) which is $20 \mathrm{~m}$ above the adjacent water table. This indiates a greater degree of confinement and/or increased pressure with depth due to hydrothermal processes.

The thermal gradient in MW:5, MW 6 and MW-7 is lower than that of the other monitor wells (average gradient of $11^{\circ} \mathrm{C} / \mathrm{km}$ ), indicating poorer hydraulic communication with the geothermal system. Total dissolved solids in MW-5 and MW-7 average $1300 \mathrm{mg} / \mathrm{L}$, while $\mathrm{MW}-6$ produces water with a TDS of $4600 \mathrm{mg} / \mathrm{L}$. Temperatures in MW-6 do not indicate natural influence from the geothermal system; however, the quality of water from this well is similar to that encountered in RRGI-6 and RRGI-7 (see Figures 4a, 4b, and 4c).

Raft River Geothermal Injection Well-4 (RRGI-4) Injection Tests. RRGI-4 injection tests during 1978 indicated vertical connection between the injection zone and shallower aquifers. ${ }^{6}$ Three of the four wells monitored 
showed positive response to each of the injection tests which ranged in length from $\mathbf{4 0}$ minutes to 10 days. Of particular interest was the response measured in the BLM Offset well. The water level in this well, which is $123 \mathrm{~m}$ deep and $1240 \mathrm{~m}$ from the injection well, rose more than $1.5 \mathrm{~m}$ during the 10-day injection test. It appears that monitor wells USGS-3, MW-1 and the BLM Offset intersect shallow fractures which are connected to the injection zone. These fractures are probably the pathways for the natural connection between the geothermal resource and shallower aquifers. RRGI-4 has subsequently been deepened to a production well. Therefore,the results of these tests may not be directly applicable to potential impacts from injection during operation of the 5MW plant. However, they do provide an indication of the nature and magnitude of the reservoir-aquifer connection.

\section{MONITOR WELL RESPONSE IN 1979}

The aquifers penetrated by the monitor well network are evidently sensitive to external influences such as barometric pressure changes, earth tides, irrigation pumping, and geothermal injection. There is no evidence to indicate sensitivity to geothermal fluid withdrawal.

\section{General Trends}

One calendar year (1979) of records from the monitor wells has been analyzed. Water level records from six monitor wells are shown in Figure 5. The hydrographs of $\mathrm{MW}-3, \mathrm{MW}-4$, MW-5, MW-6 and MW-7 illustrate one major annual cycle of ground water fluctuations, peaking at the beginning of May and declining to their lowest levels at the beginning of October.

Ground water levels rose from January until May at an average rate of $0.01 \mathrm{~m} /$ day in $\mathrm{MW}-3$, MW-5, MW-6 and MW-7. Based on long-term USGS data, this rise is a continuation of trends which usually begin in October in response to recovery from the previous irrigation season and recharge from precipitation. The period of declining water levels from May to October coincides closely with the main irrigation season and is probably a response to pumping drawdown.
Over the calendar year, the net water level decline in MW-3, 5, 6 and 7 was between 0.7 and $0.9 \mathrm{~m}$. Based on only one year of records, it is not possible to attribute this decline to specific causes . However, records from USGS-2, which include data for the longest period available for a well near the geothermal area, indicate that water levels have declined at a similar annual rate over the past four years. Water level declines from one year to the next may be due to a combination of the following:

1. Lower than average regional recharge from precipitation

2. Decreased recharge from deeper aquifers

3. Local ground water withdrawal.

A period of record covering several years will be required to identify a water budget for the geothermal area.

\section{Barometric Response}

Several of the monitor wells responded sufficiently to changes in barometric pressure for calculation of barometric efficiencies. These responses are indicated in Table 3.

The records from MW-1, MW-2, USGS-2, and USGS-3 do not allow calculation of barometric efficiencies.

\section{Response to Irrigation}

Irrigation pumping has a major influence on the shallow aquifers. The signature of the monitor well hydrographs is shaped primarily by response to irrigation withdrawals. The impact of irrigation withdrawals effectively masks any recharge from precipitation. Water levels in monitor wells 3,4 , 5, 6 and 7 and USGS-2 reflect withdrawals during the irrigation season and recovery during the remainder of the year. Monitor well 5 clearly responds to several individual irrigation wells. Monitor wells 3 and 7 appear to respond to a lesser degree to nearby irrigation wells. Monitor wells 4 and 6 and USGS-2 do not show any clearly defined response which may be correlated to 

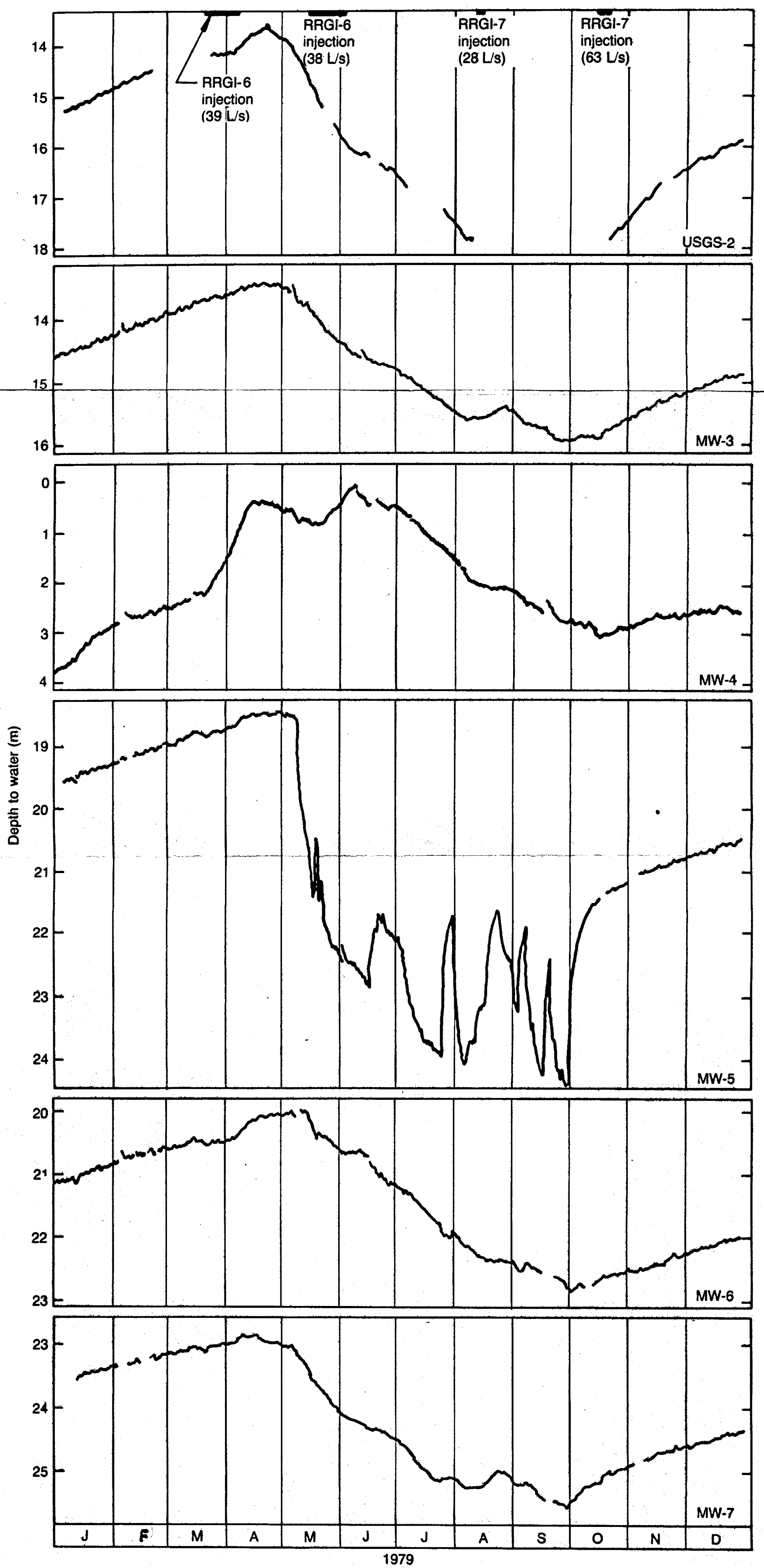

Figure 5. Water level records in 1979. 
Table 3. Barometric efficiencies of monitor wells 3 through 7

\begin{tabular}{cc}
\hline Monitor Well & \multicolumn{1}{c}{ Barometric Efficiency } \\
\cline { 2 - 2 } MW-3 & $40 \%$ \\
MW-4 & $50 \%$ \\
MW-5 & $55 \%$ \\
MW-6 & $60 \%$ \\
MW-7 & $50 \%$ \\
\hline
\end{tabular}

localized individual pumping activities. Therefore, the rate and magnitude of water level decline in monitor wells during the irrigation season probably reflects not only interference from adjacent wells but also interference from regional pumping.

\section{Responses to Geothermal Fluid Injection}

During 1979, two 21-day injection tests were conducted at RRGI-6. The first of these was conducted in March and April before the irrigation season commenced. The recovery period for the first test included part of the irrigation season and the second injection test was conducted during that same season. Monitor well responses were masked by the decline in water levels due to irrigation pumping.

Injection of geothermal fluids into RRGI-6 at depths below $525 \mathrm{~m}$ resulted in two types of response in the shallow aquifer system. During both 21-day injection tests, there was an obvious increase in water level in MW-4 in response to the injection (Figure 6). The total response, corrected for background trends, was approximately $1.2 \mathrm{~m}$ at an injection rate of $38 \mathrm{~L} / \mathrm{s}$. There was approximately four days lag time between the beginning of injection and the response in MW-4. This response indicates that relatively direct communication may exist between RRGI-6 and the aquifer penetrated by $\mathrm{MW}-4$.

At the end of the year, the water level in $\mathrm{MW}-4$ was more than $1 \mathrm{~m}$ above the level a year earlier (Figure 5). The water levels in the remaining monitor wells were as much as $1.5 \mathrm{~m}$ below that of a year before, reflecting trends recorded for USGS-2 in previous years. Even though there was recovery at RRGI-6 following both injection tests,

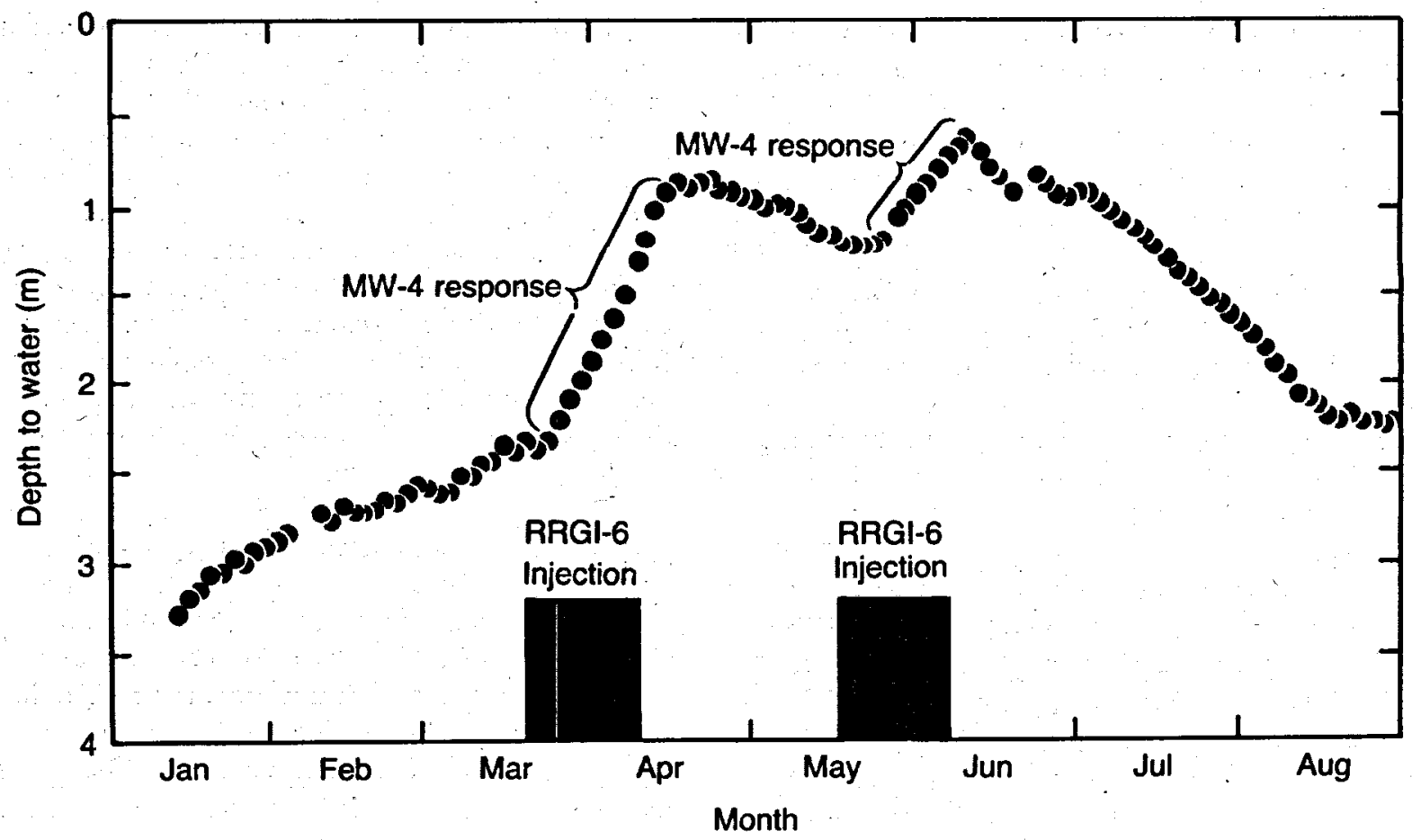

Figure 6. MW-4 water level record showing response to injection. 
there appeared to be little corresponding recovery in MW-4. The water level declines in MW-4 following injection appear to be primarily responses to regional ground water declines due to irrigation.

Three monitor wells, MW-5, MW-6 and MW-7, showed an indirect response to RRGI-6 injection. This response was a "step-function" decrease in water level which corresponded closely to the beginning and end of the RRGI-6 injection test (see Figure 7). The relative amplitude of the response appears to be related to the barometric efficiency in each well, indicating that the response may be due to elastic deformation of the aquifer matrix.

Two short-term injection tests into RRGI-7 were carried out in August and October 1979. These tests were less than 100 hours in duration, not a long enough period to produce interpretable responses in most monitor wells. However, fluctuations in water levels of $\mathrm{MW}-3$ and MW-7 coinciding with the October injection test may also represent aquifer dilation. Confident interpretation of responses requires a longer test period.

\section{Discussion}

It appears that, at least in the vicinity of $M W-4$, direct communication exists between the injection zone and shallower aquifers. The lack of immediate recovery in $\mathrm{MW}-4$ following the termination of injection to RRGI-6 may be due to the following factors:

\section{Local variations in hydraulic properties}

\section{Permeability related to pressure.}

One theory is that the communication between the injection zone and MW-4 may be along a "soft-sediment fracture."7

Sustained injection to RRGI-6 will result in a significant increase in the water level of $\mathrm{MW}-4$. With the data presently available, however, it is difficult to predict the magnitude of the increase. The significance of this projected response as a potentially degrading factor to shallow groundwater quality is difficult to quantify. It would be expected that, as a result of long-term injection, poor quality fluids in the injection zone would move up into shallower aquifers. It is important to note, however, that the undisturbed water-bearing zones intercepted by MW-4 initially contained water of poor quality, presumably because natural communication with the injection zone has existed historically.

MW-6 is at the same depth as MW-4 and is located closer to RRGI-6. However, this monitor well did not respond to injection into RRGI-6 like $M W-4$ did. The preferential nature of the injection response suggests that fractures may be the controlling mechanism for communication. If this is the case, the environmental significance of geothermal injection in Raft River will depend on the horizontal and vertical extent of these fractures.

Injection into RRGI-6 produces an apparant local matrix distortion effect on the overlying shallow aquifers. The response is reflected as a measurable decline in water levels in MW-5, MW-6 and MW-7 (see Figure 7). This response is evidently related to the elasticity of the matrix of the shallow aquifers. This matrix distortion in the shallow aquifer system did not change the normal ground water trend. Figure 7 shows that after deformation occurs, the water level curves follow the same slope trends that existed prior to and following injection.

The decline in water levels during injection represents a reduction in the piezometric surface in the shallow aquifer system of as much as $0.15 \mathrm{~m}$. This is in response to a maximum injection pressure of $1.100 \mathrm{kPa}$ above the initial hydrostatic pressure present in the injection zone. Aquifer deformation took place rapidy at the beginning of the RRGI-6 injection test, remained constant during injection, and relaxed quickly following the test. This behavior implies that distortion does not increase with the duration of the injection test, and may be primarily dependent on the injection pressure.

Assuming a linear relationship between injection pressure and distortion of the overlying aquifer matrix, hydrostatic pressure in the shallower aquifers would be reduced by $5 \mathrm{kPa}$ or less in response to projected maximum injection rates at RRGI-6. This would result in a corresponding water level decline of about $0.4 \mathrm{~m}$. This result assumes that the aquifer matrix is capable of distorting elastically by a greater degree than it has thus far demonstrated. The magnitude of this 


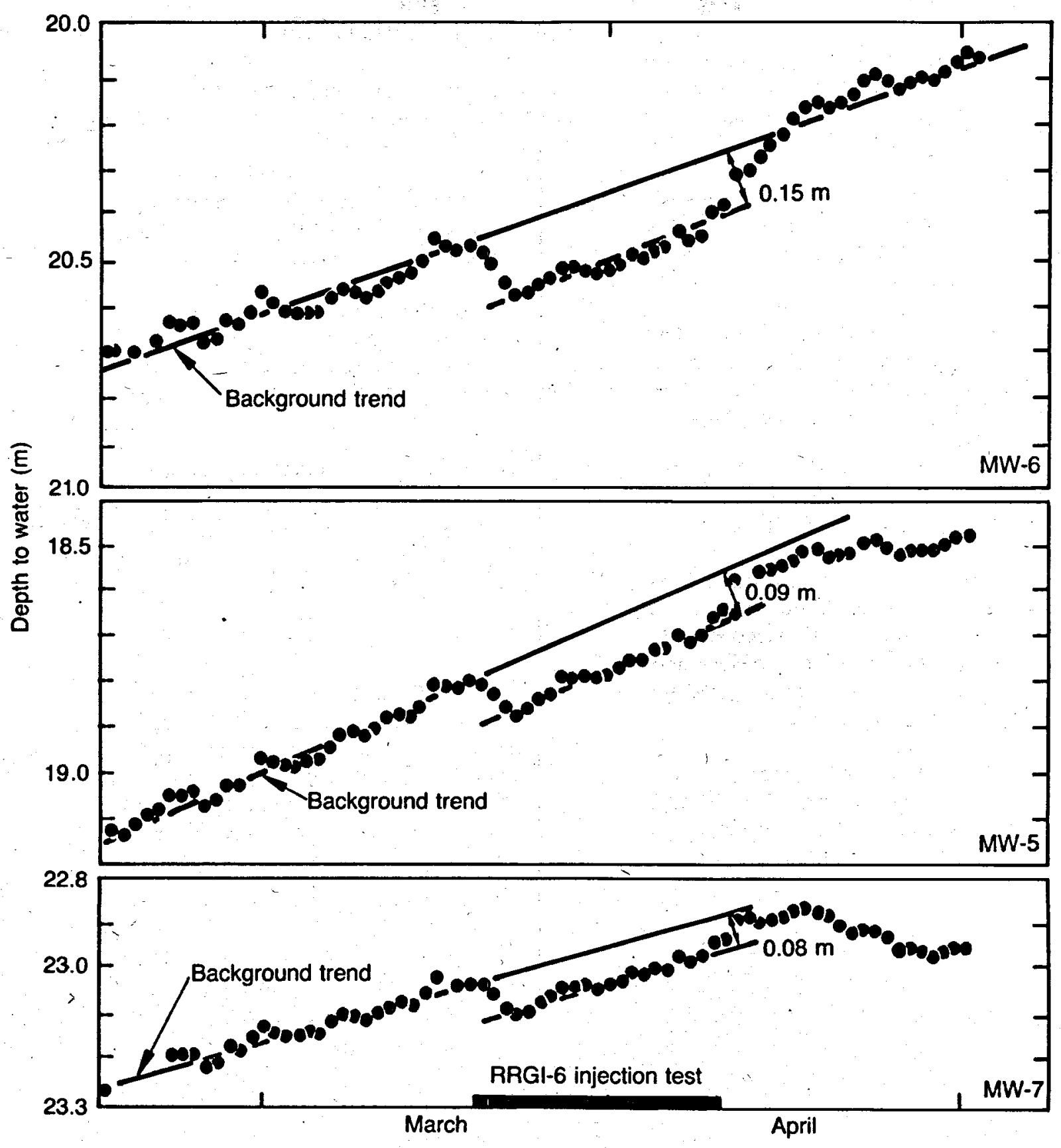

Figure 7. MW-5,6, 7 water level records illustrating aquifer distortion. 
expected pressure distortion is not great and therefore should not represent a serious environmental concern.

\section{CONCLUSIONS}

On the basis of one calendar year of records from the monitor wells, during which time two 21-day injection tests were conducted, the following conclusions may be drawn:

1. Monitor well hydrographs depict primarily irrigation withdrawal and recovery characteristics rather than a natural hydrologic cycle.

2. Monitor well 1, USGS-3, and the BLM Offset well are hydraulically connected to the injection zone in RRGI-4. This connection is probably fracture-related.

3. Monitor wells $3,4,5,6$, and 7 reflect semiconfined aquifer conditions with barometric efficiencies of $40-60 \%$.

4. Monitor well 4 shows a rapid response to RRGI-6 injection. The potential environmental impact of this response may take a long time to become evident and may not necessarily occur in the immediate vicinity of the injection wells.

5. Monitor wells 5,6 , and 7 show aquiferdistortion responses to injection through RRGI-6. These responses do not imply an immediate environmental impact.
6. Injection tests at RRGI-7 to date have not been of sufficient duration to satisfactorily identify responses in the monitor wells.

\section{RECOMMENDATIONS}

In addition to continuing the existing monitoring and chemical sampling program, the following actions should be taken:

1. Build-up pressures in RRGI-6 and RRGI-7 should be monitored carefully and continuously to detect deviations.

2. All monitor wells should continue to be observed closely, and instrumented where . necessary. Bottom-hole temperatures in MW- 4 and MW- 6 should be measured at least quarterly.

3. Land surface elevations should be accurately measured before, during, and shortly after a sustained period of injection to determine if aquifer dilation is detectable at the surface. The surveys should focus on the region of MW-5, 6 , and 7.

4. The USGS reflection seismic data presently being analyzed should be reviewed, when available, to substantiate present hydrogeologic concepts (in particular, fracture locations and orientations). Monitoring procedures should be ammended accordingly, if warranted. 


\section{REFERENCES}

1. W. D. Nichols, Simulation Analysis of the Unconfined Aquifer, Raft River Geothermal Area, Idaho-Utah, U.S. Geological Survey Water-Supply Paper 2060, 1979.

2. H. L. Overton, R. E. Chaney, R. E. McAtee, and D. L. Graham, Geochemical Modeling of the Raft River Geothermal Field, EGG-2004, November 1979.

3. A. L. Anderson, Geology and Mineral Resources of Eastern Cassia County, Idaho, Idaho Bureau of Mines and Geology Bulletin 14, 1931.

4. R. L. Nace et al, Water Resources of the Raft River Basin, Idaho-Utah, U.S. Geological Survey Water-Supply Paper 1587, 1961.

5. E. H. Walker, L. C. Dutcher, S. O. Decker and K. L. Dyer, The Raft River Basin, Idaho-Utah, as of 1966: A Reappraisal of the Water Resources and Effects of Ground-water Development, Idaho Department of Water Administration Information Bulletin 19, August 1970.

6. S. G. Spencer, J. F. Sullivan, N. E. Stanley, 1978 Annual Report, INEL Geothermal Environmental Program, TREE-1340, April 1979.

7. S. Petty, “Soft Sediment Fractures," private communication, EG\&G Idaho, Inc., January 15, 1980. 


\section{APPENDIX A}

Monitor Well Logs 
Name: MW-1

Location: SE SW Sec. 23

T 15 S, R $26 \mathrm{E}$

Date Completed: 2/3/78

Driller: Gailey Drilling

Elevation: $1475 \mathrm{~m}$

Depth to Water: Flowing

Chemistry

(mg/L)

\begin{tabular}{lr}
\multicolumn{2}{c}{$(\mathrm{mg} / \mathrm{L})$} \\
\cline { 2 - 2 } $\mathrm{Ca}$ & 215 \\
$\mathrm{~K}$ & 30 \\
$\mathrm{Li}$ & 3.7 \\
$\mathrm{Mg}$ & 0.4 \\
$\mathrm{Na}$ & 2220 \\
$\mathrm{SiO}_{2}$ & 80 \\
$\mathrm{Cl}^{-}$ & 3680 \\
$\mathrm{~F}^{-}$ & 3.4 \\
$\mathrm{HCO}_{3}-$ & 25 \\
$\mathrm{SO}_{4}^{-}$ & 66 \\
$\mathrm{pH}^{-}$ & 7.9 \\
$\mathrm{TDS}^{-}$ & 6270
\end{tabular}

Well Depth: $399 \mathrm{~m}$

Casing: $25 \cdot \mathrm{cm}$ diameter to $37-\mathrm{m}$ depth 15-cm diameter to $369-\mathrm{m}$ depth

Lithology

Perforations: None

(no temperature log available)

Legend

Vuffaceous sand

c Calcareous

Sand

$E=-$ Clay

:०: Gravel

$\begin{array}{ll}x & x \\ x\end{array}$ Limonite staining

Silt

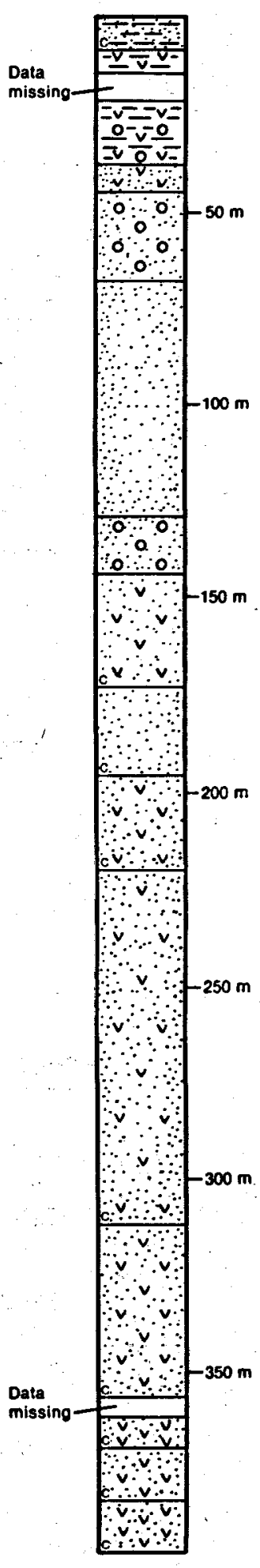

INEL-A-16 236

Figure A-1. Monitor Well-1 Log. 
Name: MW-2

Location: SE SE Sec. 23

T $15 \mathrm{~S}, \mathrm{~A} 26 \mathrm{E}$

Date Completed: $1 / 6 / 78$

Dritler: Stan Lloyd Drilling

Depth to Water: Flowing
Well Depth: $174 \mathrm{~m}$

Casing: $20 \mathrm{~cm}$ diameter to $166-\mathrm{m}$ depth

Perforations: 154-to 166-m depth

Surface Temperature: $58^{\circ} \mathrm{C}$

Bottom Hole Temperature: $106^{\circ} \mathrm{C}$

\begin{tabular}{lr}
\multicolumn{2}{c}{$\begin{array}{c}\text { Chemistry } \\
\text { (mght) }\end{array}$} \\
\cline { 2 - 2 } $\mathrm{Ca}$ & 125 \\
$\mathrm{~K}$ & 25 \\
$\mathrm{~L}$ & 2.5 \\
$\mathrm{Mg}$ & 0.5 \\
$\mathrm{Na}$ & 1000 \\
$\mathrm{SHO}_{2}$ & 87 \\
$\mathrm{Cl}^{-}$ & 1740 \\
$\mathrm{~F}^{-}$ & 5.4 \\
$\mathrm{HCO}_{3}^{-}$ & 26 \\
$\mathrm{SO}_{\overline{4}}^{-}$ & 57 \\
$\mathrm{pH}^{-}$ & 7.6 \\
$\mathrm{TOS}^{-}$ & 3190
\end{tabular}

Legend

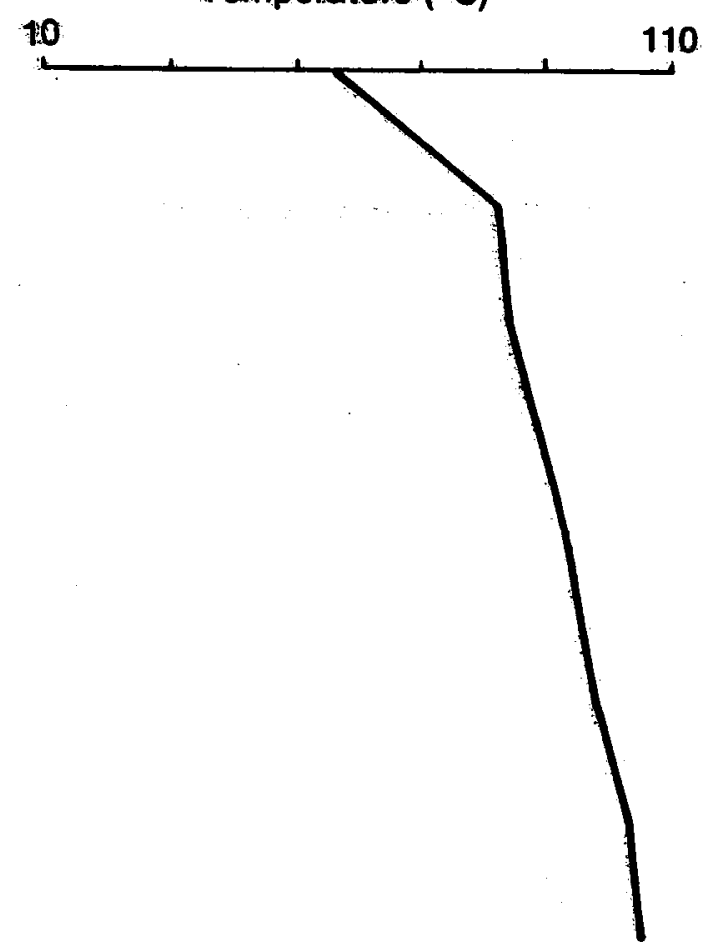

Lithology

Data

hissing

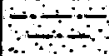

$\therefore \div \div$

$\div 0 \div-50 \mathrm{~m}$

$=0 .=0$

$\div 0 \div$

$=$

-

$\div$

E. $=100 \mathrm{~m}$

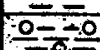

$\frac{-0-0}{0-0}$

$0=0$

$\div \div$

$150 \mathrm{~m}$

$\bar{x}: \bar{x}$

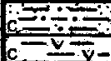

$c-\overline{y-1}$
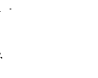

\section{viva}

Tuffaceous sand

c

Calcareous

Sand

$==$ Clay

:\%: Gravel

$x_{x}^{x}$ Limonite staining

silt

Figure A-2. Monitor Well-2.Log. 
Name: $M W-3$

Location: SENW Sec. 25

T 15 S, R $26 \mathrm{E}$

Date Completed: $8 / 1 / 78$

Driller: Stan Lloyd Drilling

Elevation: $1472 \mathrm{~m}$

Depth to Water: $15 \mathrm{~m} \mathrm{(8/1/78)}$
Well Depth: $153 \mathrm{~m}$

Casing: $30-\mathrm{cm}$ diameter to $61-\mathrm{m}$ depth

$20-\mathrm{cm}$ diameter to $153-\mathrm{cm}$ depth

Perforations: 50 slots between 140-and 153-m depth

Surface Temperature: $24^{\circ} \mathrm{C}$

Bottom Hole Temperature: $71^{\circ} \mathrm{C}$

\begin{tabular}{lr}
\multicolumn{2}{c}{$\begin{array}{c}\text { Chemistry } \\
(\mathrm{mg} / \mathrm{L})\end{array}$} \\
\hline \multicolumn{2}{|r}{} \\
$\mathrm{Ca}$ & 170 \\
$\mathrm{~K}$ & 54 \\
$\mathrm{LI}$ & 3.1 \\
$\mathrm{Mg}$ & 3.4 \\
$\mathrm{Na}$ & 1350 \\
$\mathrm{SiO}_{2}$ & 60 \\
$\mathrm{Cl}^{-}$ & 2400 \\
$\mathrm{~F}^{-}$ & 5.4 \\
$\mathrm{HCO}_{3}^{-}$ & 46 \\
$\mathrm{SO}^{-}$ & 48 \\
$\mathrm{pH}^{-}$ & 7.6 \\
$\mathrm{TDS}^{-}$ & 4300
\end{tabular}

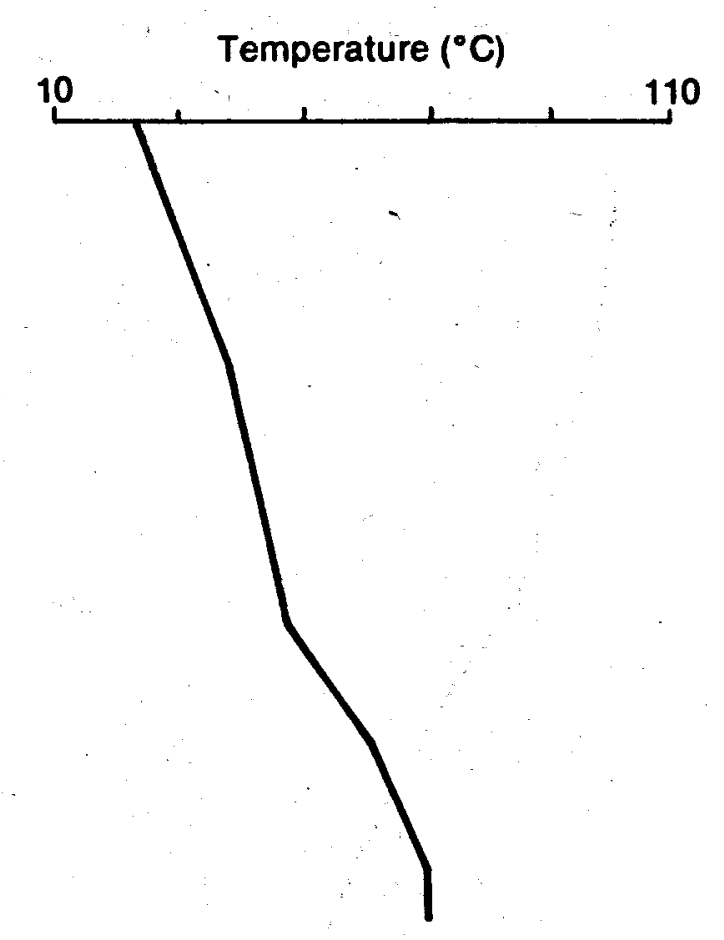

Lithology

54

3.1

3.4

1350

2400

5.4

48

4300

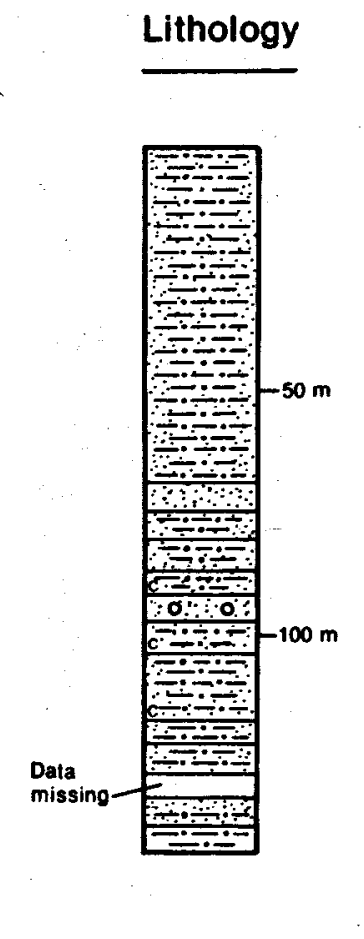

Figure A-3. : Monitor Well-3 Log. 
Name: MW-4

Location: NE NW Sec. 25

T 15 S, R 26 E

Date Completed: $7 / 31 / 78$

Driller: Stan Lloyd Drilling

Elevation: $1468 \mathrm{~m}$

Depth to Water: $3 \mathrm{~m}(7 / 31 / 78)$
Well Depth: $305 \mathrm{~m}$

Casing: $25 \mathrm{~cm}$ diameter to $171 \mathrm{~m}$ depth $20 \mathrm{~cm}$ diameter to $254 \mathrm{~m}$ depth

Perforations: 105 slots between 225-and 254-m depth

Surface Temperature: $20^{\circ} \mathrm{C}$.

Bottom Hole Temperature: $97^{\circ} \mathrm{C}$

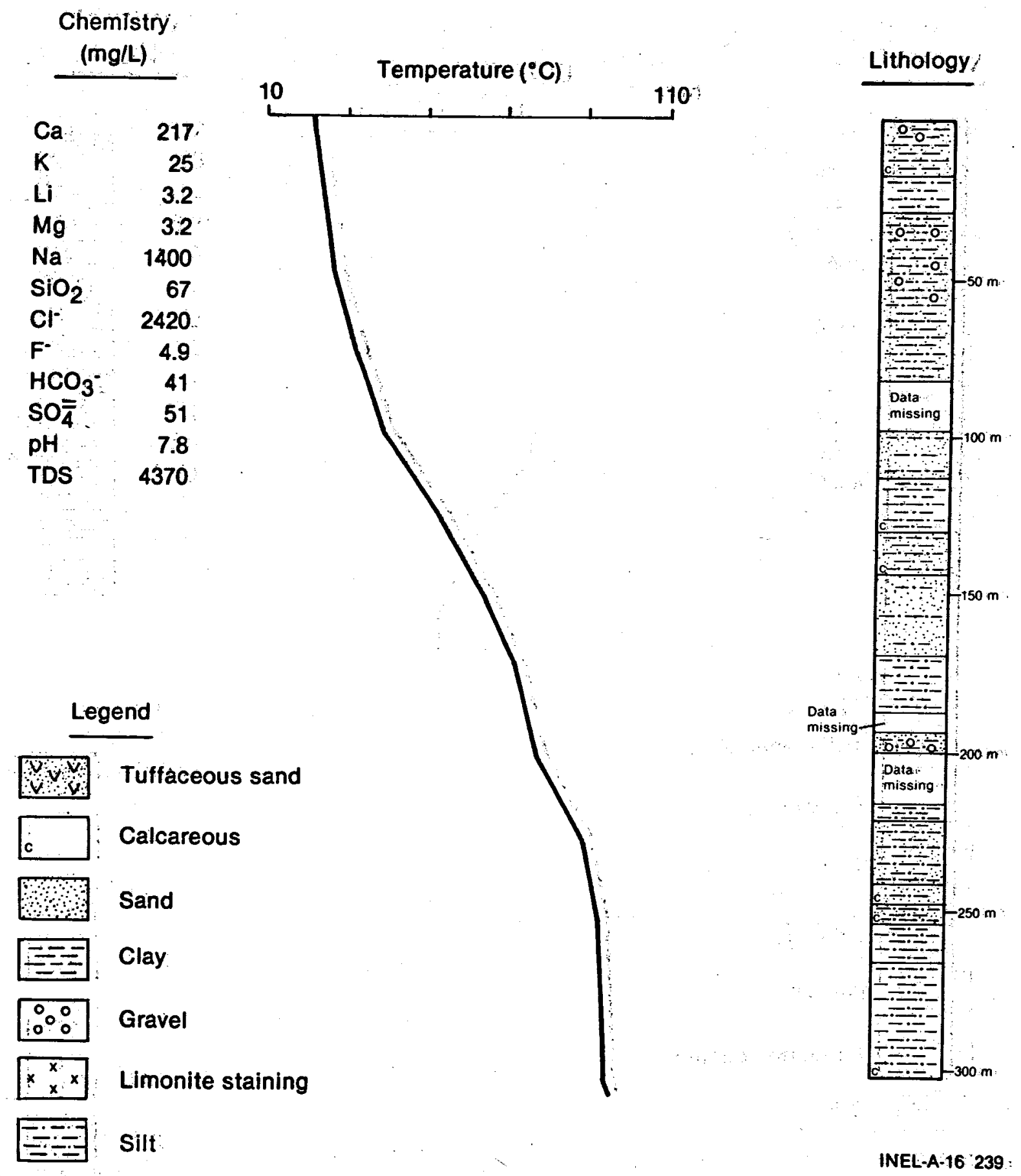

Figure A-4. . Monitor Well-4 Log. 
Name: MW-5

Location: NW NW Sec. 30

T 15 S, R $27 \mathrm{E}$

Date Completed: $8 / 20 / 78$

Driller: Stan Lloyd Drilling

Elevation: $1466 \mathrm{~m}$

Depth to Water: $22 \mathrm{~m}(8 / 20 / 78)$
Well Depth: $152 \mathrm{~m}$

Casing: $30-\mathrm{cm}$ diameter to $61-\mathrm{m}$ depth

$20-\mathrm{cm}$ diameter to $136-\mathrm{m}$ depth

Perforations: 54 slots between

124- and 136- $\mathrm{m}$ depth

Surface Temperature: $13^{\circ} \mathrm{C}$

Bottom Hole Temperature: $28^{\circ} \mathrm{C}$
Chemistry

(mg/L)

$\begin{array}{lr}\mathrm{Ca} & 107 \\ \mathrm{~K} & 14 \\ \mathrm{Li} & 0.3 \\ \mathrm{Mg} & 25 \\ \mathrm{Na} & 230 \\ \mathrm{SiO}_{2} & 29 \\ \mathrm{Cl}^{-} & 717 \\ \mathrm{~F}^{-} & 0.6 \\ \mathrm{HCO}_{3}^{-} & 101 \\ \mathrm{SO}_{4} & 27 \\ \mathrm{pH}^{-} & 7.8 \\ \mathrm{TDS} & 1229\end{array}$

Legend

Tuffaceous sand

c Calcareous

Sand

$E=$ Clay

$\because 0:$ Gravel

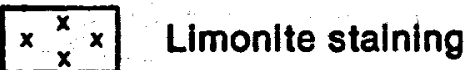

silt
Lithology

Temperature $\left({ }^{\circ} \mathrm{C}\right)$

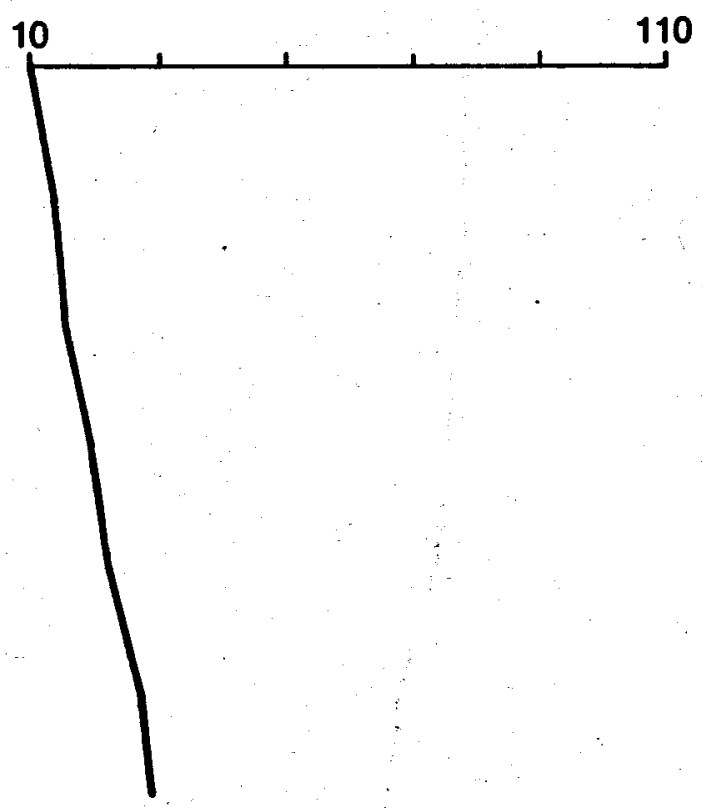

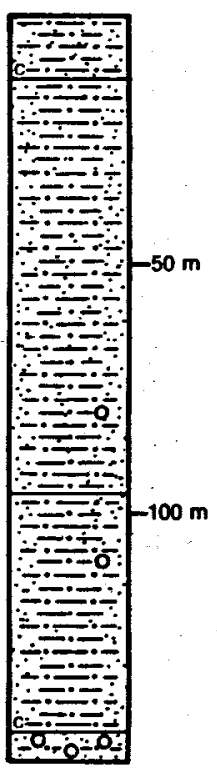

INEL-A-16 240

Figure A-5. Monitor Well-S Log. 
Name: MW-6:

Location: SE NW Sec. 30

T15 S, R 27 E

Date Completed: $6 / 15 / 78$

Driller: Gailey Drilling

Elevation: $1469 \mathrm{~m}$

Depth to Water: $21 \mathrm{~m}$ (3l.1/79):
Well Depth: $305 \mathrm{~m}$

Casing: $25-\mathrm{cm}$ diameter to $46-\mathrm{m}$ depth $15-\mathrm{cm}$ diameter to $274-\mathrm{m}$ depth

Perforations: None

Surface Temperature: $11^{\circ} \mathrm{C}$,

Bottom Hole Temperature: $44^{\circ} \mathrm{C}$

Chemistry

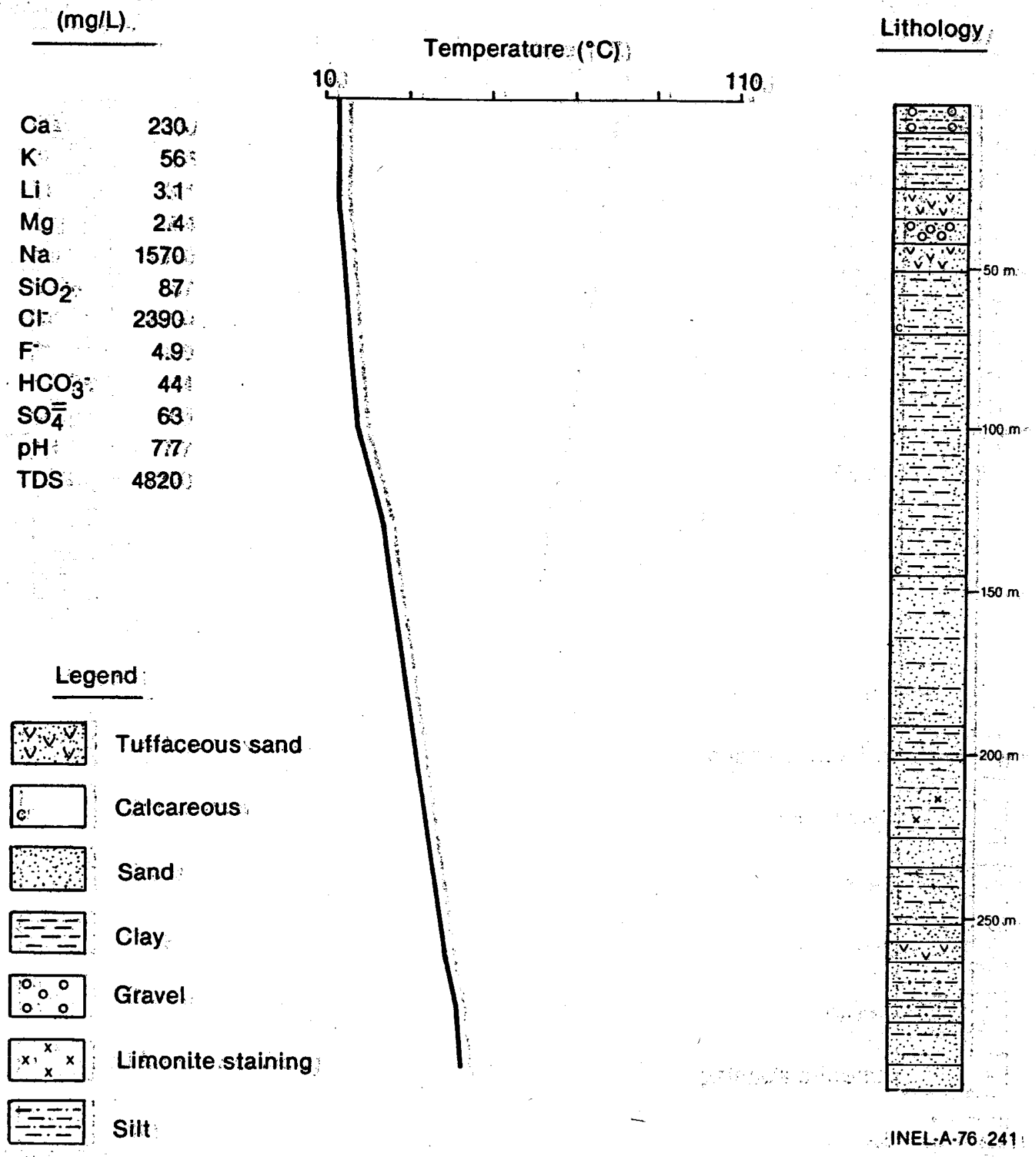

Figure A-6, Monitor Well-6 Log. 
Name: MW-7

Location: NE SE Sec. 25

T 15 S, R $26 E$

Date Completed: $9 / 6 / 78$

Driller: Stan Lloyd Drilling

Elevation: $1474 \mathrm{~m}$

Depth to Water: $21 \mathrm{~m}(9 / 6 / 78)$
Well Depth: $152 \mathrm{~m}$

Casing: $30-\mathrm{cm}$ dlameter to $61-\mathrm{m}$ depth $20-\mathrm{cm}$ diameter to $152-\mathrm{m}$ depth

Perforations: 50 slots between 140-and 152-m depth

Surface Temperature: $20^{\circ} \mathrm{C}$

Bottom Hole Temperature: $35^{\circ} \mathrm{C}$

\begin{tabular}{lr}
\multicolumn{2}{c}{$\begin{array}{c}\text { Chemistry } \\
\text { (mg/L) }\end{array}$} \\
\hline & \\
& \\
$\mathrm{Ca}$ & 110 \\
$\mathrm{~K}$ & 7.6 \\
$\mathrm{Li}$ & 12 \\
$\mathrm{Mg}$ & 1.6 \\
$\mathrm{Na}$ & 29 \\
$\mathrm{SiO}$ & 350 \\
$\mathrm{Cl}^{-}$ & 36 \\
$\mathrm{~F}^{-}$ & 1.0 \\
$\mathrm{HCO}_{3}^{-}$ & 107 \\
$\mathrm{sO}_{4}$ & 32 \\
$\mathrm{pH}^{-}$ & 8.0 \\
$\mathrm{TDS}^{-}$ & 1380
\end{tabular}

Temperature $\left({ }^{\circ} \mathrm{C}\right)$
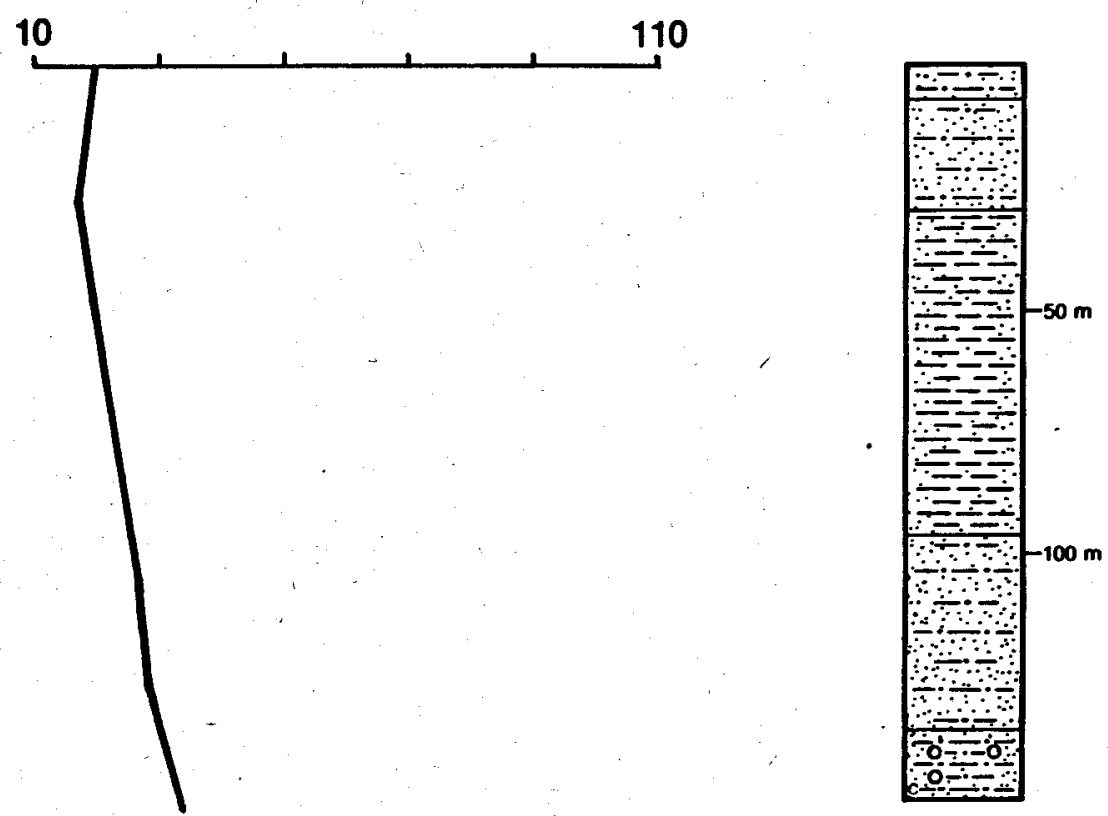

Legend

Tuffaceous sand

Calcareous

Sand

$==$ Clay

$\left[\begin{array}{ll}0 & 0 \\ 0 & 0 \\ 0\end{array}\right]$ Gravel

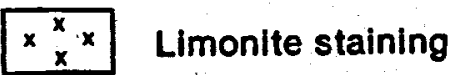

Silt

Figure A-7. Monitor Well-7 Log. 